\title{
A ECONOMIA DAS CANARIAS NOS SÉCULOS XIV E XV
}

\section{CAPfTULO I}

\section{RELAÇÕES DA CRISTANDADE COM AS ILHAS CANÁ- RIAS NOS SÉCULOS XIII, XIV e XV. AS FONTES.}

Conhecidas dos romanos sob o nome de Ilhas Afortunadas e dos islamitas sob o de Ilhas Eternas (Al-Halidat), as Canárias' parece que nāo estiveram integradas na navegação sistemática quer de cristãos quer de muçulmanos até o século XIV. Visitaram-nas provàvelmente alguns aventureiros antes da tomada de Lisboa aos mouros (1147), e da existência de tais ilhas persistiu um conhecimento vago. Que os muçulmanos as nāo frequentavam, conclui-se do estado económico do arquipélago ao ser conquistado pelos europeus e ainda de nāo desempenhar qualquer funçāo na economia marroquina; aliás, as relações do Maghreb com a Guiné teciam-se por caravanas que atravessavam o deserto, e nāo por via maritima. A corroborar esta inferência, dispomos do assêrto de Ibne Khaldun (2." metade do século XIV) de que só por acaso e nāo intencionalmente os navios vāo parar às ilhas Canárias (1).

O descobrimento das Canárias pelos cristāos data das últimas décadas do século XIII. Em Maio de 1291 desaferravam de Génova as duas galés Allegranza e Sant'Antonio, capitaniadas por Ugolino e Vadino Vivaldi; pretendiam os dois irmāos alcançar as. Indias pelo mar Ocidental e levavam consigo mercadores para estabelecer o comércio e dois franciscanos para realizarem a evangelização. Em Génova foram-se recebendo notícias da viagem: os dois navios tocaram em Maiorca, Barcelona, Valéncia, Alicante. Cádiz, entraram no Attântico, aportaram a Gozora (zona entre Agadir e o Cabo Nāo): e a partir daqui nada mais se soube da expedição. Ora, a mais setentrional e oriental das ilhas Canárias. denominou-se desde o século XIV Allegranza - precisamente o nome de uma das galés dos Vivaldi. É muito possivel que os genoveses tivessem estado nessa ou noutra ilha (supõe-se hoje que chegaram pelo menos à Senegâmbia e há quem avente que devem ter ido mesmo muito mais longe). O promotor e principal capitalista da expediçāo, Tedisio d'Oria, organizou possivelmente novas.

(1). - Monumenta Cartographica Africne et Aegypti, tomo IV, fl. 1340 v. 
viagens em busca do paradeiro dos Vivaldi. Em tais navegações é que se deve ter batizado a ilha com o nome de uma das galés que se buscavam.

A esta década final de Duzentos ou ao primeiro lustro de Trezentos deve remontar uma expediçāo armada genovesa a que se refere Petrarca em De vita solitaria: nas Ilhas Afortunadas "eo patrum memoria januensium armata classis penetravit". Como o poeta nasceu em 1304, a indicaçāo "segundo a memória de nossos pais" data o envio da frota de guerra de alguns anos atrás. É possivel que se trate da expedição organizada por Tedisio d'Oria e é certo que se não trata da dos Vivaldi; mas pode muito bem ser outra que nāo a que ia em demanda dos exploradores perdidos.

É ainda um genovês quem realiza a primeira conquista de uma das ilhas Canárias, supõem alguns que seduzido pela noticia de a elas terem arribado uns marinheiros de Cherburgo (elemento possivel mas aliás desnecessário, pois vimos que em Génova se conhecia a existência do arquipélago). A viagem e estadia de Lanzarotto (ou Lancillotto) Malocello (ou Maroxello) realizou-se talvez entre 1310 e 1330 (efectivamente, o navegador figura já como testemunha num acto dêste último ano); alguns historiadores recuavam-na para 1275, o que levaria a identificá-la talvez com a expediçāo referida por Fetrarca; mas é significativo que a ilha nāo apareça mencionada no planisfério de Angelino Dalorto (1325) e figure já na cópia que dêle fêz Angelino Dulcert catorze anos depois: nesta segunda carta vemos pela primeira vez: insula de Lanzarotus Marocellus. O nome encontra-se também no Atlas Mediceu de 1351. Entretanto, o arquipélago tornava-se bem conhecido aos cristãos. Em 1337 já Petrarca podia escrever: “... da Bretanha, da Irlanda e de tôdas as Órcades a setentriāo do Oceano Ocidental, e das Ilhas Afortunadas a meio-dia do mesmo, tanto por experiência como por informações dos viajantes que constantemente por ai passam, tẽem-se pouco menos notícias do que da Itália ou da França" (2). Por conseguinte, os europeus deviam já frequentar as ilhas com certa regularidade. Lanzarotto Malocello construira na ilha do seu nome um castelo, cujas ruínas a expedição de Jean de Béthencourt e Gadifer de la Salle ainda encontrou em 1402 (3); o fundador fôra, ao que parece, expulso por uma revolta dos indigenas, depois de uma permanência de talvez cêrca de dezoito anos.

A primeira descriçāo de algumas das ilhas é a que nos deixou Giovanni Boccacio, resumindo cartas de mercadores florentinos de Sevilha, com data de 15 de Novembro, chegadas a Florença ainda cm 1341 (4). Em 1 de Julho dêste ano partiram de Lisboa dois

(2). - Im tudo o que antecede seguimos Rinaldo Caddeo, Le Navigazioni Atlantiche (Milẽo 1929), Introdução, e Ch. La Roncière, I.

(3). - Pierre Bontier e Jean Le Verrier: Historia del Primer Descubrimiento do las Canarias (cap. XXX).

.(4). - A tradução portuguesa em Documentos sôbre a Expansĩo, vol. I, cap. I. 
navios e um barco mais pequeno, com equipagens de florentinos, genoveses, castelhanos e catalães; o florentino Angiolino del Tegghia de' Corbizzi capitaneava a frota, que o rei de Portugal provera de todo o necessário para a passagem e que levava material de guerra para efectuar conquistas; o genovês Niccoloso de Recco era capitāo de um dos navios. A expedição regressou em princípio de Novembro, sem ter chegado a realizar qualquer estabelecimento nas ilhas. Trouxe quatro cativos, peles de carneiro e de cabra em abastança, sebo, óleo de peixe, peles de lobos marinhos e madeiras tinturiais. Na descrição da viagem só se dá o nome de uma das ilhas visitadas: a Canária (Grā-Canária); todos os historiadores estão de acôrdo em identificar a primeira ilha visitada com Forteventura; mas quanto às restantes, a identificação não é fácil ou é mesmo desesperada: é possivel que os três navios tenham percorrido os arquipélagos madeirense e açoreano, além de visitarem demoradamente o canariano. Em todo o caso, para o objectivo que nos propômos, tais dificuldades nāo importam muito, visto que só se descrevem, sob o ângulo económico-etnográfico, as duas ilhas bem identificadas. A importância de tal descriçāo nāo pode ser sobre-estimada: dá-nos o estado da Canária e de Forteventura num momento em que a acçāo cristā ainda nāo devia ter exercido influência de relêvo nestas duas ilhas, e só passadas mais de seis décadas nos surge outra fonte a focar os aspectos que nos interessam. Os navegadores não só viram com vagar as ilhas, como ainda tiveram prolongado contacto com os indigenas cativos.

Uma bula de 15 de Novembro de 1344, passada por Clemente VI, concedeu o senhorio das Canárias, mediante o pagamento de um tributo anual, ao conde de Talmont, D. Luis de la Cerda, bisrieto de Afonso X o Sábio, de Castela, e neto de S. Luis de França. $O$ pontífice pediu a vários reis que auxiliassem a conquista. Mas - donatário nāo conseguiu os meios para a efectuar. E em 12 de Outubro do ano seguinte Afonso IV, rei de Portugal, protestava contra a concessão, embora declarasse acatar a vontade pontificia (5). O protesto baseava-se em três argumentos:

a) argumento geográfico da vizinhança: as Canárias estāo mais perto de Portugal do que de qualquer outro reino;

b) argumento histórico da prioridade no descobrimento: "os nossos naturais foram os primeiros que acharam as mencionadas ilhas":

c) argumento histórico da prioridade na conquista: o rei português já lá enviara uma armada e já tinha deliberado a conquista, adiada devido à guerra com Castela e à guerra com os mouros.

$O$ primeiro argumento é manifestamente verdadeiro, o segundo manifestamente falso. Vimos já que o descobrimento se deve.

(.) . Idem. 
sem sombra da dúvida a genoveses e que em 1337 era corrente a navegação para as Canárias. Petrarca escrevia em Da vita solitaria no mesmo ano do protesto português: "... as Ilhas Afortunadas. situadas no extrêmo Ocidente, como aquelas que nos [à Cristandade] sāo mais vizinhas e melhor conhecidas" (6). Mas o terceiro argumento é igualmente falso: Génova iniciara há tempo já a conquista do arquipélago e ocupara mesmo 'a ilha de Lançarote, facto que a cartografia italiana nāo esqueceu no século XIV nem no século XV. A manifesta falsidade da argumentaçāo explica porque é que o Papa nāo atendeu o protesto. A própria narraçāo de Boccacio apresenta já o descobrimento das Canárias como vulgarmente conhecido.

Ter-se-ia mesmo realizado a expediçāo alegada por Afonso IV? A invocaçāo das guerras com Castela e com os mouros para justificar o nāo prosseguimento da conquista data-a o mais tardar de 1336. Damião Peres propõi identificar tal viagem com a narrada por Boccacio; nesta descriçāo haveria um êrro de cópia na data - MCCCXXXXI por MCCCXXXVI; a identificaçāo assentaria na absoluta igualdade de pormenores das duas pretensas viagens (7). Esta afirmação não me parece de forma alguma aceitável. O monarca declara que enviou naus tripuladas por portugueses, as quais abordaram às ditas ilhas e se apoderaram por fôrça de homens, animais e outras cousas e os trouxeram para Portugal. Quanto ao primeiro ponto, é flagrante a discordância com Boccacio, pois no relato dêste as tripulações sāo de florentinos, genoveses, castelhanos e outros espanhois (ao contrário do que pensa Damiāo Peres, nāo é nada evidente que êstes sejam os portugueses). Quanto aos outros dois pontos, as indicações da carta do rei são demasiado vagas para se falar em pormenores; mais ainda: Afonso IV diz que os canários trazidos foram cativos pela fôrça em terra, ao passo que Boccacio descreve que vieram a nadar até os navios e êstes desaferraram com êles a bordo. Além disso, nada demonstra que a viagem de 1341 fôsse de iniciativa portuguesa; - relato parece dar a entender o contrário. Supôs Caddeo que o rei invoca falsamente tal expediçāo como portuguesa; em sentido oposto, argumentou Peres que, se assim procedesse, o rei de Portugal nāo deixaria de encontrar na cúria pontifícia quem o desmentisse: o argumento carece, porém, de valor, porquanto das três razões invocadas pelo monarca, duas sāo notòriamente falsas.

A carta dos Pizzigani, de 1367, traz a representaçāo de quási todo o arquipélago, com o emblema de Génova e a figuração de navios genoveses e venezianos navegando para o Sul. Estes dados cartográficos concordam com as informáçóes de Petrarca. E tais conhecimentos nāo se perderam: no Atlas Catalāo de 1375

(6). - Citado por Rinaldo Caddeo, ob. cit.

(7). - História dos Descobrimentos Portugueses, pág. 14-15. 
lá vem o nome de Lanzarotto Malocello e a bandeira da repúblicá de Génova (que se repetirāo na carta de Mecia de Viladestes de 1413 e até na de Pareto de 1455) (8). O Atlas Catalčo só nāo regista a Palma.

Em meados de Trezentos, segundo nos informa Ibne Khaldun, realizou-se outra grande expediçāo cristā ao arquipélago. Os "fran$\cos ^{\prime \prime}$ (= europeus) atacaram os indigenas, pilharam os seus haveres e cativaram pessoas, que foram vender aos portos marroquinos. Êstes cativos entraram ao serviço do sultāo, e aprenderam a lingua árabe; por êles soube-se em Marrocos alguma cousa da civilizaçāo insular, e tal foi a fonte onde Ibne Khaldun colheu os dados, infelizmente tāo concisos, que nos subministra (9).

A expediçāo relatada pelo historiador muçưlmano nāo é com lôda a certeza a narrada por Boccacio, pois divergem em pontos fundamentais. Por essa época - 1340 a 1350 - realizaram-se várias viagens de europeus ao arquipélago. Duas delas são-nos conhecidas pelos livros da chancelaria de Maiorca, onde ficaram registadas as nomeações para os comandos das frotas. "Cinco meses apenas sôbre o regresso da, tāo falada em Sevilha, expedição de 1341, o lugar-tenente do rei de Maiorca concedia a Francisco Desvalers a capitania de uma expediçāo que se dirigia às ilhas de Fortuna "noveylament trobades". Dias depois, a um Domingo Gual e outros, fazia o dito lugar-tenente uma concessão semelhante para irem "a las ylles noueylament trobades a les parts de ponent". Dez anos mais tarde o papa Clemente VI nomeia o primeiro bispo das Canárias. Em 1369 o sumo pontífice recomenda aos bispos de Barcelona e Tortosa uns religiosos que se propõem ir às Canárias, prova de que a Catalunha e Maiorca constituiam entāo focos de navegaçāo para o arquipélago. Um catalāo Jacme Ultzina, é feito em 1394 bispo de Canária. Oito anos atrás Pedro III de Maiorca rogara ao papa protecção a uns eremitas que se propunham ir ao arquipélago com fito religioso.

Mas também de outros portos peninsulares se navegava para lá. Assim, temos notícia de que o biscainho Martin Roiz de Avendaño foi às ilhas Canárias em 1377 (9a).

$\mathrm{Na}$ segunda metade do século XIV deve ter continuado a navegação italiana e castelhana, e até talvez portuguesa, para as Canárias. Fortunato de Almeida (10) e Edgar Prestage (11) falam mesmo de uma tentativa de conquista das ilhas Lançarote e Gomeira por Lançarote da Franca, almirañte do rei de Portugal D: Fernando; a tentativa, de entre 1370 e 1376, ter-se-ia gorado devi-

(S). - Caddeo, ob. cit.

(9). - M C A A t. IV fl. 1340 v.

(9a). - Sobre esta informação e o parágrafo que antecede veja-se a Historia da Expansaio Portuguesa, I, 271-2.

(10). - Historia de Portugal, vol. III, págs. 759-80.

(11). - Descobridores Portugueses, pág. 30 . 
do à oposiçāo armada dos indígenas e de castelhanos. Mas a autenticidade dos três documentos que nos fornecem tais informações suscita dúvidas que continuam por resolver.

Nesses documentos aponta-se como causa do fracasso da tentativa de Lançarote a oposiçāo dos indigenas e de castelhanos. A leitura da História do Primeiro Descobrimento das Canárias sugere igualmente que por volta do fim do século XIV e princípio do século XV os castelhanos, sobretudo de Sevilha, frequentavam assiduamente o arquipélago; parece que iam à ilha de Lobos caçar lobos marinhos, mas também visitariam outras ilhas para obter cativos e mercadorias (12). Em 1393, cinco naus de Sevilha, capitaneados por Gonçalo Peraza Martel, tinham saqueado Lançarote, regressando com grande despojo (Hist. Exp. Port., I, 272). E em relaçāo com êsses meios de Sevilha nos aparece o primeiro conquistador quatrocentista das Canárias. Do pôrto de La Rochelle partem, em 1 de Maio de 1402, o cavaleiro e barāo normando Jean de Béthencourt e o cavaleiro Gadifer de la Salle, em um ou dois navios; passam por Cádiz, onde se detêem algum tempo, e daqui aportam, ao fim de oito dias, à ilha de Graciosa, desembarcando em Julho na ilha de Lançarote; consigo traziam mulheres francesas. Nesta última edificam o castelo de Rubicon e estabelecem amizade com o rei e os nativos. Béthencourt regressa a Espanha a fim de obter refresco de mantimentos e socôrro de gente e armas; como estava muito na graça do rei de Castela, presta-lhe homenagem e consegue a concessāo do senhorio das ilhas, e do direito do quinto das mercadorias que de lá viessem para Espanha, além de um auxilio de 20.000 maravedis. Entre os seus direitos senhoriais ficou a contar-se o de cunhar moeda nas Canárias. Entretanto, Gadifer organizava uma expediçāo e dava a volta pelas ilhas de Forteventura, Grä-Canária, Gomeira, Ferro e Palma, numa viagem que durou três meses e em que se combateu com os indígenas, se fizeram cativos e se exploraram as ilhas. Jean de Béthencourt volta para Lançarote e então emp:eende-se a sistemática cristienizaçāo da ilha. Em 1404 efectua-se a demorada conquista de Forteventura, com a construção de dois castelos. No ano seguinte, o barāo normando vai a França, levando consigo 3 canários e uma canária para que aprendam os costumes franceses e depois os ensinem aos nativos; reune 160 homens de armas, alguns.

(12). - Cap. IX: o navio Morella comandado por Francisco Calvo, esta fundeado na itha de Lobos em 1士02 (pág. 9-10). Cap. XT: o navio Tajamar, de Fernando de Ordonez, chega passados dias is ilha Graciosa (pág. 11). Cap. X.IV: o rei indigena de Linçarote, aprisiontdo à traicão pelos normandos, consegue fugir pela sexta vez de mãos cristãs (pág. 14). Cap. XXX: Jean de Iréthencourt, ao vir de Françal pela primeira vez para as ilhas, trouxe consigo um canário para servir de intérprete (pág. 30). Cap. XL: Gadifer encontra na Girä-Canária o testamento de 13 cristãos que aqui morreran em 1391, depois de terem habitado na ilha sete anos (pág. 41). Cap. XLII; a itha do Ferro está quási despovoada em 1402 porque os cristãos costumavam salteá-1a para fazer cativos - só nesse ano foram raptados 400 nativos (pág. 42). 
dos quais levam as mulheres, e um certo número de artifices e lavradores que irāo civilizar as ilhas em tôdas as artes e oficios. Desta vez conquistam-se mais as ilhas da Palma e do Ferro, e nesta última estabelecem-se 120 casais de colonos; em Lançarote e Forteventura ficaram as familias de mesteirais. Jean de Béthencourt organiza as ilhas colonizadas e manda que se guardem na medida do possivel, os costumes de França e Normandia (13). Em ambas estas ilhas se edificaram e funcionaram duas igrejas. $\mathrm{Em} .15$ de Dezembro de 1405 o barāo normando regressou definitivamente ao pais natal: a Guerra dos Cem Anos, com a ocupaçāo da Normandia pelos ingleses, obstou-o de enviar reforços e manter relações com as ilhas, cujo senhorio alienou em 1418.

A conquista das Canárias por Jean de Béthencourt foi narrada pelos dois capelāes que o acompanharam, Pierre Bontier, franciscano, e Jean Le Verrier, presbítero. A obra deve ter sido composta, pelo menos em grande parte, ainda em vida do conquistador, mas contem aditamentos posteriores à sua morte (1425) — pode ser, aliás, que apenas as duas ou três ultimas páginas. É, cronològicamente, a terceira fonte de interêsse etnográfico em relaçāo às Canárias. Descrevem-se sistemàticamente as ilhas Lançarote, Lobos, Forieventura, Grā-Canária, Tenerife, Gomeira, Palma e Ferro: quere dizer, todo o arquipélago, com a excepçāo sem importância da Allegranza e da Graciosa. A descriçāo assenta na observaçāo directa, e numa observaçāo directa não ocasional, fugaz, mas sim que durou alguns anos, como fruto de estadia prolongada nas ilhas e contactos intimos e constantes com os seus habitantes. Sem dúvida, é o ponto de vista dos conquistadores, e relativo a uma data em que já há bem mais de meio século as Canárias estavam em relaçāo com a Cristandade, tendo mesmo sido ocupada a ilha de Lançarote durante vários anos ou até mais de uma década. Em todo o caso, nāo parece difícil determinar com alguma precisão em que consistiram êsses contactos: ocupação da ilha de Lançarote, caça regular aos lobos marinhos ná ilha de Lobos, saltear de certas ilhas (especialmente Ferro) para cativar escravos, comércio com a ilha de Lançarote e possivelmente com a de Forteventura e outras (ou melhor, aquisição pelos cristāos, pelos mais variados meios, de sangue de dragão, sêbo, peles, urzela). A situação da economia e sociedade indigenas alterou-se com certa profundidade devido à conquista e colonizaçāo de Lançarote, Forteventura e Ferro de 1402 a 1405 . Por conseguinte, as fontes posteriores já nāo podem ter o mesmo valor que a História do Des-

(13) - O relato que fazemos resume o livro de Jean Le Verrier e Pierre Bontier. Os acontecimentos aparecem timbém referidos em Zurara, Crónira da Guine (cap. LXX1X), em Diogo Gomes, em Valentim Fernandes (que segue Zurara e Gomes) e em João de I3arros (Calp. XII, Livro I, Decada 1), que segue Zurara.

Cf. Charles La lioncisare: Histoire de la Dëcouverte de la Terre, pág. $\$ \bar{z}-\mathrm{S}$. 
cobrimento e Conquista das Ilhas Canárias: esta obra ocupa assim uma posição excepcional. Mas as suas indicações de carácter económico-social sāo mais vagas e menos abundantes do que as de descrições mais tardias.

Ao regressar definitivamente a França, em fins de 1405, Jean de Béthencourt deixou como capitāo das ilhas o sobrinho Maciot; êste depois conquistou a Gomeira com o auxilio dos castelhanos, que sempre o continuaram a prover do necessário; como o tio, Maciot reconhecia a soberania do rei de Castela (14). Em 1424 ou 1425 Portugal organizou uma armada, em que foram 2.500 homens de pé e 120 de cavalo; o comando coube a D. Fernando de Castro. A frota atacou a Grā-Canária, mas a tentativa fracassou, parece que à míngua de mantimentos embora se realizasse a conversāo de parte dos indígenas; no ano seguinte Castela opôs-se a novo empreendimento (15). Catorze anos depois D. Fernando de Castro comandou nova frota que foi às Canárias, sem resultados positivos (Archivo Historico Portuguez, vol. I, págs. 346-7). Mas em 1447 o Infante D. Henrique contratava com Maciot de Béthencourt a compra do senhorio da ilha de Lançarote, a trôco das saboarias e outras rendas da Madeira; e Antāo Gonçalves foi tomar posse da ilha em nome do Infante e aí permaneceu algum tempo; Castela, porém, interveio novamente, alegando que o donatário nāo tinha poderes fara vender o senhorio e jurisdição, de direito pertencentes à coroa castelhana: e D. Henrique desistiu (16).

A Crónica dos Feitos de Guiné, que consagra quatro capitulos à descrição das Canárias, é já posterior a êstes acontecimentos. Mas é muito provável que tais capitulos figurassem já na Crónica de Cerveira: na verdade, $Z$ urara declara segui-lo no que respeita. ao Infante D. Henrique ter requerido a el-rei os direitos de $\mathrm{Ca}$ nária em 1446 (cap. LXXXV). Se assim for, tal descrição data o mais tardar de 1446. Ignoramos, no entanto, as fontes que Cerveira utilizou. O cronista descreveu apenas quatro das ilhas: Grā-Canária, Gomeira, Tenerife e Palma; mas dá o cômputo da populaçāo de Lançarote, Forteventura e Ferro. Quere dizer: a descriçāo incide sôbre as ilhas que ainda nāo estavam conquistadas e cristianizadas - aquelas que Portugal cobiçava. E sintomático que, embora no cap. LXXIX se fale na conquista e cristianizaçāo parcial da Gomeira por Maciot e pelos castelhanos, no cap. LXXX a ilha nos apareça ainda inteiramente pagã e sem civilização: será que Cerveira incluiu na sua Crónica uma descrição anterior a tal acontecimento? É muito possivel, e aventaria até que essa descrição precede a tentativa portuguesa de 1424: quem sabe se nāo é a compilação das informações colhidas para preparar tal emprêsa

\footnotetext{
(14). - Zurara, Crón. da Guine, cap. LXXIX, e Joāo de Barros, Década I, Livro I, cap. XII.

(15), - Idem, idem.

(16). - Crón. da Guine, cap. XCV, e Barros. cap. XII.
} 
(lembremo-nos de Ceuta)? A corroborar tal assêrto, está a circunstância de que nunca se omite a referência às armas e forma de peleja dos nativos das quatro ilhas, o que de suma maneira interessava para uma expediçāo militar. Como o cronista se mostra bem informado dos feitos de Jean de Béthencourt, poder-se-ia supor que conhecia a obra de Bontier e de Le Verrier; esta hipótese .é absolutamente contraditada por uma comparação entre os dois monumentos; focam aspectos diversos: baste apontar que os dois capelāes não descrevem o armamento e peleja, nem as formas de familia e relações sexuais dos canários, temas prediletos da Crónica da Guiné. Para as questões económicas, é a obra de CerveiraZurara a mais importante de tôdas.

Em 1455, na sua viagem para a Guiné. Alvise da Cada Mosto passou pelas Canárias e esteve nas ilhas Gomeira e Ferro, ambas já de cristāos. Quere dizer que entretanto se devem ter passado na Gomeira os acontecimentos referidos por Valentim Fernandes: os canários mataram o capitāo cristāo, o que determinou nova conquista com expulsāo de todos os indigenas da ilha (17). Cadamosto dá-nos informações gerais sôbre o arquipélago e seus habitantes, e descreve em especial a ilha de Tenerife. Além da observaçāo directa - restrita - qual é a origem das suas informações? Com certeza, o que the contaram os marinheiros portugueses e os cristāos das duas ilhas que visitou; êstes conheciam os costumes das ilhas dos idólatras da seguinte forma: costumavam ir salteá-las para fazer cativos (que depois vendiam como escravos em Espanha), $e$ às vezes alguns cristāos ficavam prisioneiros dos indígenas, que, em vez de os matarem, os utilizavam como magarefes, profissāo entre êles a mais vil (18).

Em De Insulis Primo Inuentis In Mar Oceano Ocidentis Diogo Gomes enumera as ilhas Canárias, indica as que permanecem idólatras e descreve precisamente estas, que sāo: Grā-Canária, Tenerife e Palma. Como Diogo Gomes várias vezes navegou para a Guiné, é natural que tenha visitado o arquipélago, embora o nāo indique expressamente. As suas informações, de interêsse para o estudo das crenças e costumes, mal aludem ao aspecto económico ou nem o chegam a fazer, o que tira a esta fonte quási tôda a importância para o escôpo que marcámos.

$\mathrm{Na}$ coletânea de Valentim Fernandes vem inserta uma descrição das ilhas do mar oceano, por aquele impressor elaborada. E já obra muito tardia, pois data do segundo lustro do século XVI: Alonzo de Lugo conquistara Tenerife e Palma, em 1495 e 1496. Esta descrição justapõi o que se lê em Zurara e em Diogo Gomes, por vezes em forma abreviada; todavia acrescenta informações relativas a acontecimentos posteriores àquelas fontes e indicações de

(17). - o Manuscrito, fol. $154 \mathrm{r}$ (pág. 104):

(18). - Navegação Primeira, cap. V. 
carácter económico que nelas nāo figuravam (mas que em grande parte representam resultados subsequentes da colonizaçāo cristā). A descrição da ilha do Ferro é inteiramente nova, bem como a de Forteventura. Afigura-se-me muito plausivel que Valentim Fernandes colhesse tais dados durante a sua estada em Sevilha, o pôrto de mais activo comércio com as Canárias.

Já em meados do século XVI, consagrou Joāo de Barros um capitulo (o XII) do livro I da Década I às Canárias; a primeira parte historia as relações dos cristāos com as ilhas $e$ as disputas àcêrca do seu senhorio até fim do século XV, o que completa. ùtilmente as informações de Valentim Fernandes; mas na segunda parte, descritiva-etnográfica, limita-se a reproduzir o que dissera. Zurara, carecendo por isso de todo o valor como fonte.

Nāo conhecemos documentos diplomáticos portugueses do século $X V$ que possam elucidar qualquer aspecto económico da vida insulâr. Para tal não servem decididamente a carta régia de 3 de Fevereiro de 1446 , que concede a D. Henrique o exclusivo da navegaçāo para as Canárias (da qual só se extrai que os portugueses as frequentavam para comércio e pirataria), nem a carta henriquina de 9 de Março de 1448, àcêrca do pagamento das rendas. a Maciot Béthencourt (19). 


\section{CAPfTULO II}

\section{AS PRIMEIRAS ILHAS CONQUISTADAS PELOS EURO- PEUS: LANÇAROTE, FORTEVENTURA, LOBOS, FERRO}

O arquipélago das Canárias dispõe-se, grosso modo, na direcção do paralelo, entre $27^{\circ}$ e meio e $29^{\circ}$ e meio de latitude setentrional, quere dizer, desde as alturas do ued Assaca, ao Norte, até às do ued Seguiet-el-Hamra, ao Sul; cabe entre os meridianos de $16^{\circ}$ e $21^{\circ}$ de longitude ocidental, ficando a ilha de Forteventura apenas a $100 \mathrm{~km}$ do Cabo Jubi. Compõe-se o arquipélago de șete ilhas e cinco ilheus, que se chamavam, segundo João de Barros: Alegrança, Santa Clara, Graciosa, Lançarote, Lobos, Forteventura, Roque, Grä-Canária, Inferno (ou Tenerife), Gomeira, Palma e Ferro (20). As três primeiras (21), a quinta e a sétima sāo pequenas e despovoadas.

De formaçāo vulcânica, com amplas crateras - "caldeiras" centrais onde a actividade eruptiva nāo se extinguiu por completo em algumas das ilhas, gozam de clima temperado graças ao alisado do Nordeste no verāo, conquanto o sirocco do Sáara atinja o grupo levantino, que do deserto recebe também nuvens de gafanhotos e tempestades de areia. A influência saariana repercute ainda na vegetaçāo "sobretudo nas ilhas orientais, onde dominam as plantas gordas e os arbustos espinhosos. As grandes eufórbias cactoides, os dragoeiros (Dracaena) sāo muito característicos. $\mathrm{Na}$ zona média húmida subsistiram alguns trechos de florestas de Laurus nobilis, de Pinus canariensis, de Erica arborea, outrora mais extensos. Mais alto mostram-se giestas brancas, os retem" (22).

Povoadas por berberes denominados guanchos, as Canárias, conquanto de onde a onde recebessem a visita de algum barco europeu ou norte-africano, permaneceram pràticamente isoladas até o século XIV, fóra de qualquer das rotas de navegaçāo habituais, e só na era de Quatrocentos passariam à escala do tráfico marítimo. Daí o carácter anacrónico da sua civilizaçāo, o terem cristalizado no estado que Morgan e Childe designam por "barbárie"." Ignorava-se por completo a metalurgia; mas a forma de existência era a sedentariedade, consistindo a actividade económica na agricultura, pastoreio e recoleçāo. Ibne Khaldun nos seus Prolegómenos

(20) . - Década I, Livro I. cap. XII.

(21) . - Diogo Gomes.

(22) . - Bernard, II, 387-8. 
(fins do século XIV) deixou-nos ótima definiçāo da situaçāo dos insulares, aurida nas informações de alguns cativos: "Contavam, entre outras cousas, que cavam a terra com cornos para a semear, e que o ferro é desconhecido no seu país; alimentam-se de cevada, e o seu gado consiste em cabras; combatem com pedras que arremessam; prosternam-se diante do sol ao nascer e nāo conhecem religiāo revelada nem foram catequizados por qualquer missāo religiosa" (23). Estes dados reportam-se essencialmente às três ilhas maiores - Forteventura, Grā-Canária e Tenerife -, todavia valem em conjunto para todo o arquipélago. É de notar, porém, que as pesquisas de Verneau revelaram que "os guanchos da ilha do Ferro possuíam o segrêdo de uma escrita hieroglifica" (24).

A primeira ilha que os europeus frequentaram regularmente $e$ colonizaram foi a de Lançarote, que os naturais chamavam Tite Roy-gatra (25). Esta ilha nāo é descrita na narraçāo de Boccacio, de 1341; a primeira descriçāo que dela possuimos pinta-a ao dealbar a era quatrocentista, a quando da sua conquista pelos normandos; quere dizer que nos é impossivel determinar o estado da economia e da sociedade indígenas antes da penetraçāo cristā ou independentemente dela. Ignoramos como é que Lanzarotto Malocello se estabeleceu na ilha e qual a amplitude da sua colonizaçāo, e, por conseguinte, quais as transformaçöes económico-sociais que daí decorreram.

Parece, porém, que a ilha de Lançarote era muito povoada no século XIV. Com efeito, Jean de Béthencourt e os seus companheiros encontraram ainda muitas aldeias, mas algumas com a populaçāo diminuida e outras abandonadas. Bontier e Le Verrier atribuem o ermamento à acção dos corsários espanhois e de outras nações, que por muitas vezes saquearam a ilha e arrebataram numerosos cativos (26); a explicação é plenamente verossímil. Em 1402 a sua populaçāo não ultrapassava 300 habitantes, segundo o cômputo dos invasores (27). Na Crónica da Guiné, que se reporta já a alguns anos depois da conquista e colonização da ilha, escreve-se que tem 60 homens (cap. LXXIX); deve entender-se este número como indicação ùnicamente dos guerreiros e nāo de todos os moradores (como revela o confronto entre os números do mesmo capitulo e os do cap. LXXXII no que respeita à ilha de Gomeira). O estabelecimento dos normandos na ilha nāo parece ter-se efectuado por meios muito violentos, porquanto nāo encontraram oposiçāo (o que denota que os nativos já se tinham acostumado à presença de cristāos). Mas logo passado pouco tempo, no intervalo da primeira ida de Béthencourt a Espanha, Bertin de Berneval

(23). - M C A A, t. IV fl. 1340 v.

(24). - La Roncière, Hist. Déc. de Ia Terre, p. 88 .

(25). - Bontier e Le Verrier, cap. LXXX (pág. 75).

(26). - Idem.

(27). - Idem, cap. XIıIII (pág. 43) e LXXI (pag. 75). 
atraiçoa a fidelidade ao capitāo Gadifer de La Salle e, rompendo os compromissos com os indigenas, apodera-se cavilosamente do rei e mais 23 insulares (28); o rei conseguiu escapar, mas os restantes cativos seguiram para Cádiz e foram vendidos em Aragāo (29). Esta deslealdade quebrou a confiança dos indígenas nos cristāos e levou-os a afastar-se (cap. XXIX, pág. 29); como consequência, reatou-se a guerra e os canários refugiaram-se nos montes e cavernas (cap. XXXIII, págs. 32-3); Gadifer chega a conceber o projecto de matar todos os homens e só deixar com vida as mulheres e crianças (cap. XXXIV, pág. 33), e pelo menos intervem nas lutas politicas pela realeza entre as facções indígenas (cap. XXX, pág. 30). A pacificaçāo nāo demorou. porém. muito tempo (estava terminada em 1403), e com ela progrediu cèleremente a cristianizaçāo, que Béthencourt organizou sistemàticamente ao regressar ao fim de uma ausência de alguns meses. Dai por diante as relações dos intrusos com os naturais caracterizaram-se pela brandura e compreensāo, nāo mais se registando violências. Em 1404, os indigenas de Lançarote combateram já ao lado dos normandos contra os indigenas de Forteventura (30).

Inicialmente, o número de normandos que vieram fixar-se em Lançarote foi com certeza baixo. Béthencourt e Gadifer partiram de La Rochelle com um ou dois navios e parece que 80 marinheiros, dos quais 27 lhes fugiram em Cádiz (cap. III, pág. 4). Mas logo nesta primeira leva seguiram também mulheres francesas, pois nelas nos falam ao relatar a traiçāo de Bertin de Berneval (31). Os que primeiro vieram deviam ser exclusivamente cavaleiros e servidores, além dos dois capelāes, e nāo lavradores ou mésteirais. Em 1405 é que Jean de Béthencourt vai a França buscar colonos que desenvolvam na ilha a agricultura $e$ as artes e ofícios, bem como refôrço de guerreiros para prosseguir a conquista. Passados quatro meses regressava, acompanhado de 160 homens de peleja, 23 dos quais traziam as mulheres, e umas dezenas de familias de lavradores e artifices (32). Dêste afluxo de colonos nāo podemos, contudo, determinar qual o número dos que ficaram em Lançarote. $\hat{E}$ natural pensar que a vinda de colonos mais do que compensou a diminuiçāo do número de indígenas provocada pela conquista. No fim do século XV ainda continuava a falar-se em Lançarote o dialecto normando (33).

A ilha de Lançarote é em grande parte plana, só escabrosa de entrar do lado da ilha Graciosa (34). Apresenta-se nua de arvoredo (35), só com pequenos arbustos que dão um leite no sé-

\footnotetext{
(28). - Idem, cap. XII (pág. 12-3). -

(29). - Idem, cap. XXV (pág. 24).

(30). - Idem, cap. IXXXIII (pág. 78).

(31) - Idem, cap. XVII (pág. 16).

(32). - Idem, cap. LXXIX (pág. 90-1) e LXXXV (pág. 101).

(33). - La Ronciere, Hist. de la Decouverte de la Terre, pág. 88.

(34). - Bontier e Le Verrier, cap. LXXI (pág. 75).

(35). - Idem; V. Fernandes, fol. $148 \mathrm{v}$ (pág. 101); "Aruoredo tem nenhuum."
} 
culo XV considerado muito medicinal (36). Nāo se encontram rios nem ribeiras, e por isso o problema da água teve de ser resolvido pelos homens pela utilizaçāo das fontes e escavaçāo de poços (que são de boa água). Construiram-se cisternas e foi-se ao ponto de fazer canos para conduçāo da água da serra para as planícies, recolhendo-a num lugar como estanque (chamado Maretas); esta água bastava para a criaçāo de gado (37). Parece que tais obras existiam já, pelo menos em parte, antes da vinda dos franceses, porquanto Gadifer, ao acender-se a guerra com os indígenas, destruiu fontes e cisternas (bem como lavras) e nāo é muito plausivel que tivessem sido os guerreiros a ensinar como a cousa se fazia; mas durante o século XV, com a colonizaçāo por lavradores e mesteirais, com certeza tais construções hidráulicas foram aperfeiçoadas, até se chegar ao que Valentim Fernandes descreveu.

Bontier e Le Verreir declaram que Lançarote é abundante de pastos (cap. LXXI, pág. 75). A criaçāo de gados tinha de facto muita importância, consistindo sobretudo em cabras, conforme se lê em Valentim Fernandes (fol. 146 v, pág. 101). Cadamosto confirma que existiam muitas cabras em meados de Quatrocentos ( $\mathrm{Na}$ vegaçāo Primeira, cap. V). No fim do século XV havia também muitos coelhos, mas mais nenhuns animais (38).

As terras da ilha prestavam-se a boa lavoura, na apreciaçāo dos dois capelāes; mas, pela sua natureza, nāo davam para a sementeira de trigo (embora a houvesse), esclarece o impressor de Morávia. A grande produçāo consistia em cevada (39). De cevada fazia-se por isso bom pão, consoante informam Bontier e Le Verrier (cap. LXXI, pág. 75). Ignoramos se antes do estabelecimento dos normandos, os indigenas saberiam já panificar os cereais; nas outras ilhas que mais tempo permaneceram idólatras nāo conheciam a arte da panificaçāo, mas em Lançarote podiam ter aprendido com os genoveses de Malocello no século XIV.

Estas produções condicionavam o regime alimentar. Sabemos por Cadamosto (meados do século XV) que a alimentaçāo dos habitantes de Lançarote (já todos cristãos) se compunha de pão de cevada, carne de cabra e leite de cabra. Não tinham trigo, a nāo ser quando o importavam, nem vinho, e a fruta era pouca (40). A ilha era bem provida de sal, lê-se no cap. LXXI da História de Bontier e Le Verrier (pág. 75). É natural que a alimentaçāo

(3i). - Bontier e Le Verrier, idem.

(37). - V. Fernandes, fol. $146 \mathrm{v}$ (paf. 101): "IEsta ilha he sem ribeyras dagoa porem tem pouços de boa agoa. E assim os moradores della fizerō como canos amtre as serras pera vijr a agoa toda pera baixo a huum lugar como estanque em q se recolhe toda a agoa daquellas serras'.; Bontier e Le Verrier, idem.

(38). - Y. Fernandes, pig. 101: ". . nesta ilha ha grãdes criações de cabras." ; "Ha nesa ylha muytos coelhos e nenhuum outro animal."

(39). - Idem: "As mais de suas sementeyras he de ceuada por a tem pouco trigo por causa da terra." ; Bontier e Le Verrier, cap. LXXI (pág. 75).

(40). - Navegagno Primeira, cap. 'V. 
antes da conquista só diferisse do que veio a ser posteriormente em nāo ter (?) pāo, utilizando papas de cevada em sua vez.

No começo de Quatrocentos, os nativos do sexo masculino andavam nus, só com uma espécie de capa que dos ombros descia até os joelhos; as mulheres vestiam uma como que opalanda de pele (certamente de cabra) que lhes chegava até os pés (41).

$\mathrm{Da}$ organização da sociedade insular quási nada sabemos. $\mathrm{Pa}$ rece que um rei presidia a tôda a ilha com as suas numerosas aldeias. As fontes não nos falam em divisāo em bandos, como para as outras ilhas. Estava constituida a familia na base da poliandria: a mulher tinha geralmente três maridos; êstes alternavam as funções conjugais consoante os meses; o homem que ao fim de um mês de relações sexuais cede o seu lugar a um dos dois outros maridos passa a servir no mês seguinte, juntamente com o terceiro que não entrou em funçāo conjugal, como criado da mulher (42). A existência da realeza e o que se passava no resto do arquipélago sugerem-nos que a sociedade se hierarquizava provàvelmente em familias nobres e gente comum: mas as fontes emudecem a tal respeito. Também ignoramos qual a constituição da propriedade antes da invasāo normanda.

Jean de Béthencourt parece ter introduzido na ilha o regime senhorial, mas em forma mitigada. A partir de então houve certamente cavaleiros e lavradores, os primeiros vivendo nos castelos. A administração da justiça ficou confiada a dois alcaldes (43). $\mathrm{O}$ conquistador procedeu a uma distribuiçāo das terras, contemplando com melhor quinhāo os seus normandos do que os indígenas (o que os dois capelāes achavam de inteira justiça). O rei indigena ficou com um solar e 300 ou 400 acres de terra de lavoura (44). Cada colono recebeu uma casa e terras, pelas quais esteve isento durante 9 anos, findo o qual prazo passou a pagar - quinto de dinheiro, gado e cereais. Para os curas pagavam os moradores $1 / 30$ (45). A maior porcentagem das rendas a que o senhor tinha direito ficou destinada durante cinco anos à construçāo de igrejas.

Com o domínio normando, a itha de Lançarote deixou de ser salteada e de constituir, portanto, centro de abastecimento de escravos, e integrou-se, durante as primeiras décadas do século, no tráfico europeu corrente. A urzela crescia em abundância pela ilha, dando-a a terra sem cultivo (46); como tinha grande importância na indústria de tinturaria dos panos, e por isso valia muito (47). constituiu primacial mercadoria de exportaçāo. Jean de Béthencourt

(41). - Bontier e Le Verrier, cap. IXXXX.

(42). - Tdem.

(43). - Idem, cap. LXXXV (pág. 102).

(44). - Idèn, cap. LXXXVI (pág. 104-5).

(45) . - Idem, cap. LXXXY (pág. 101).

(46). - Idem, cap. LXXXV e LXXI.

(47). - Idem, cap. XXXVI (pág. 36). 
reservou para si o monopólio da urzela, que ninguém mais podia vender a nāo ser com sua autorizaçāo e pagamento de um direito (48). Cadamosto corrobora as primeiras informações dos companheiros do conquistador, mostrando o seu texto que continuavam a ser válidas algumas décadas mais tarde; por 1455 seguiam das Canárias grandes quantidades de urzela que afluiam a Cádiz e Sevilha e daqui eram distribuidas para Levante e Poente (Navegaçāo Primeira, cap. V). Pelo navegador veneziano sabemos ainda que Lançarote exportava courama de cabras, grossa e muito perfeita, muito sebo e bons queijos de leite de cabra (idem). Mas já em 1402 os armadores de Sevilha mandavam a esta ilha buscar couros, sebo, urzela e sangue de drago (49), e tal comércio parece até anterior à conquista. Na ilha encontravam os navios dois excelentes portos, de segurança e bem utilizáveis (50). Por tôdas estas razões os capelāes de Béthencourt esperavam que à ilha acorressem muitos mercadores e mercadorias (cap. LXXI, pág. 76).

Entre as ilhas de Lançarote e Forteventura situa-se o ilheu de Lobos, a uma légua de cada uma delas, segundo o cálculo de Valentim Fernandes (pág. 101). Esta ilha era deserta antes de 1402 (51), e despovoada permaneceu durante todo o século XV. Não havia água doce nem se produziam quaisquer mantimentos; quem aqui vinha estancear alguns dias para caça precisava de trazer consigo tôdas as provisões (52). Mas a ilha tinha grande importância económica. Efectivamente, era maravilhoso o número de lobōs-marinhos que a ela acudiam; ora, a courama e o óleo dêstes anfibios constituiam mercadorias muito estimadas (com as peles fabricava-se calçado) (53). Bontier e Le Verrier calculavam que as peles e a gordura dos lobos-marinhos desta ilha poderiam render por ano mais de quinhentas dobras de ouro (54). Para mais, a Sudoeste abria-se um bom pôrto para galés e naus; no começo do século frequentavam-no os navios dos armadores de Sevilha (55).

A duas léguas de Lançarote fica a ilha de Forteventura. É muito provável que fôsse a primeira ilha visitada pela expedição de 1341. Não parece, porém que os cristāos a tenham ocupado no século XIV, e foi só a segunda a ser conquistada por Jean de Béthencourt e Gadifer de la Salle. Nestas circunstâncias, podemos, graças a descriçāo de Boccacio e à História do Descobrimento e Conquista das Canárias, determinar as caracteristicas económicas e sociais da ilha anteriormente ao estabelecimento europeu. Não

\footnotetext{
(4\$). - Idem, cap. LXXXV.

(49). - Idem, cap. XXXVI (pág. 36).

(50). - Idem, cap. LXXI. valentim Fernandes fala só de um pôrto: "Tem porto e emtrada ao noroeste." (fol. 148 r, pág. 101.).

(51). - Bontier e Le Verrier, cap. XI (pág. 11) e LXXI (pág. 75).

(52). - Idem, XI (pấg. 11).

(53). - A importancia da caça ou pesca aos lobos-marinhos ressalta da Cronica da Guinc.

(54). - Bontier e Le Verrier, cap. LXXI (pág. 75). Cf. cap. XI (pág. 10).

(55). - Gadifer de la Salle viu a nau Morella, de Francisco Calvo, fundeada na ilha de Lobos (Idem, cap. IX, pág. 9-10).
} 
significa o que acabamos de dizer que tal quadro seja independente da interferência cristā: - certamente os europeus saltearam Erbania (nome indigena da ilha), aprisionaram cativos e até adquiriram os produtos insulares no decurso da era de Trezentos. Em todo o caso, a posição não é a mesma que em relação à ilha de Lançarote.

Os navegadores de 1341 viram a ilha de Erbania pedregosa e revestida de selvas, tôda salpicada de cabras. A pintura feita pelos capelāes do conquistador é já mais discriminada. Parte da ilha está coberta de areia (56). Uma montanha parece que domina a paisagem; há aí uma fonte de água viva e corrente. Perto da serra, corre o riacho das Palmas: ao longo do seu curso alinham-se as palmeiras, muito cerradas. Abre-se depois um vale plano, sumamente delicioso, por onde serpenteiam vários arroios e em que se erguem mais de 800 palmeiras (57). Além dos bosques de tamareiras, junto aos riachos cresciam bosques de árvores que distilam uma goma branca mas cuja madeira nāo serve para construçāo; havia igualmente árvores de leite considerado medicinal e ainda de outras espécies, bem como zambujeiros e lentiscos (58). Um século mais tarde, Valentim Fernandes indica que "Esta ilha tem matos pequenos" e esclarece que "Esta ilha tem poucas agoas de ribeyras e salobras. E as mais das agoas sam de poços e boõs" (59). Estas indicações nāo contradizem o quadro anterior: também Bontier e Le Verrier afirmam de que por tôda a ilha se podem abrir poços de água salobra $(60)$.

A vida económica antes da conquista normanda girava tôda à volta da criaçāo de cabras: a sua abundância impressionou os florentinos, genoveses e espanhois da expediçāo de 1341. Bontier e Le Verrier sublinham que há mais dêste gado miúdo em Erbania do que em qualquer outra ilha, e avaliam (de certo com forte exagêro) que se poderiam abeter por ano 60.000 cabeças; os dois capelèes deliciam-se com o proveito que adviria do metódico aproveitamento dessas cabras que rendem tanta gordura: aproveitar a carne e o sêbo daria por cabra 30 ou 40 libras (61). Num só ataque a uma aldeia de Erbania colheram os franceses 1.000 cabras (cap. LXXIV, pág. 80). Em meados do século, Cadamosto fala (Navegaçāo Primeira, cap. V) da grande exportaçāo de courama, sebo e queijo de cabra. Valentim Fernandes dirá mais tarde: " $E$ cria muytas cabras e muytos coelhos" (fol. 148 r, pág. 101); mas os coelhos, que nāo são referidos pelas fontes anteriores, devem ter sido introduzidos pelos cristāos.

(56). - Idem, cap. LXX (pág. 73)

(5i). - Idem, cap. XXXVII (págs. 37-8). Cf. Cap. V (pág. 6).

(5). - Idem, cap. LXX (pág. 73).

(59). - Fol. 148 r (pág. 101).

(60). - Bontier e Le Verrier, cap. LXX (pág. 74).

(61). - Idem. 
$\mathrm{Na}$ ilha desdobram-se boas terras para lavrar (62). Nāo parece, contudo, que os indígenas se consagrassem à semeadura de cereais, embora seja provável que a realizassem em pequena escala no que respeita à cevada. Bontier e Le Verrier nāo incluem as papas de cevada na alimentação dos nativos de Erbania, prova de que, a existirem (o que me parece de aceitar), não desempenhavam papel de relêvo.

O regime alimentar baseava-se quási exclusivamente na utilizaçāo da cabra. Segundo os dois capelāes, a alimentaçāo indígena constava de: carne sêca (mas nāo salgada, pois nesta ilha nāo usam o sal) (63), que os franceses aliás achavam melhor e mais saborosa do que a de França; sebo, que os canários comiam como os cristãos comiam o pão; e queijos de leite de cabra, muitos e bons (64). Bontier e Le Verrier acentuam que os nativos se alimentam quási só de carne (cap. LXXIII, pág. 78). Depois da conquista normanda, o pāo de cevada veio adicionar-se a esta ementa, mas no resto a alimentação manteve-se igual (65).

O vestuário dos canários de Erbania resumia-se a peles de cabras, segundo a descriçāo da História do Descobrimento das Ilhas (cap. LXXVII, pág. 86). Mas os navegadores de 1341 afirmam que homens e mulheres andam nus. Para resolver a contradição entre os dois testemunhos, podem alvitrar-se duas hipóteses: progresso de civilização no decurso da segunda metade do século XIV (devido talvez a influência europeia através da ilha de Lançarote); ou generalizaçāo apressada por parte dos homens de Angelino del Tegghia e de Nicoloso de Recco: nāo teriam tido ensejo de observar que certos individuos usam ou que em certos estados ou situações se usam peles de cabras. O que se passava nas outras ilhas inclina-nos para a segunda hipótese.

Os indigenas eram de alta estatura. Os componentes da expediçāo de 1341 viram-nos "selvagens nos costumes e ritos" e nāo ousaram penetrar no coraçāo da ilha com receio dêles. Bontier e Le Verrier, que os consideram de entendimento duro, dizem que êles são muito guerreiros (66) e que dificilmente se deixam cativar (cap. LXX). Nāo tinham armamento defensivo, e como armas ofensivas utilizavam ùnicamente pedras que arremessavam e chuços de pau (cap. LXXVII, pág. 86). Parece que o estado de guerra era endémico na ilha, por isso coberta de como que castelos; os dois reis guerreavam-se constantemente (idem, pág. 86-7). Os indigenas tinham os seus templos, onde efectuavam sacrifícios, e mostravam-se, no dizer dos dois capelāes, muito apegados às suas crenças (67).

(62). - Idem.

(63). - Idem.

(64). - Idem.

(65). - Cadamosto, Navegacão Primeira, cap. T.

(66). - Bontier e Le Verrier, cap. LXXIlI (pag. 78).

(67). - Idem, cap. LXX (pág. 74). 
Do estado social e organização da ilha antes da conquista sabemos só o que antecede, e que existiam dois reis, que entre si dividiam o senhorio de Erbania.

As operações normandas contra Forteventura tiveram como base a ilha de Lançarote. Logo durante a primeira estada de Jean de Béthencourt nesta ilha foi uma expediçāo à ilha vizinha; mas os nativos retiraram-se para o outro extremo de Erbania, e assim Gadifer e os companheiros permaneceram oito dias no interior sem incidentes, e aliás também sem contactos pacíficos (68). Após a chegada da nau com viveres e com 80 soldados de refôrço que o barāo normando enviou de Castela; Gadifer vai percorrer as ilhas e primeiramente desembarca em Erbania; interna-se em direcçāo ao riacho das Palmas, entra no vale das palmeiras e mais adiante trava combates com os indigenas aprisionando quatro mulheres, depois do que reembarca (69). Em 1404 é o próprio Jean de Béthencourt que vai atacar Forteventura e aqui faz cativos; permanece na ilha três meses, mandando construir uma fortaleza na encosta da montanha a uma légua do mar junto a uma fonte de água viva, no sitio chamado Rico Roque (70): ao saltear sucedia a conquista e ocupaçāo. Pouco depois, uma pequena expediçāo que fôra reconhecer a Grā-Canária passa por Erbania e encontra aqui castelhanos que tinham desembarcado e estavam embuscados para fäzer cativos (cap. LXIII, págs. 65-6). Mas neste ano Béthencourt regressa a Espanha e durante a sua ausência os nativos conseguem reconquistar e destruir o castelo (7i). O donatário de Lançarote ainda voltou nesse mesmo ano e mandou reedificar a fortaleza de Rico Roque em 1 de Novembro de 1404 (72). As lutas prosseguiram, porém, e foram numerosos os recontros com os indigenas, embora êstes combatessem quási só com pedras. Num ataque a uma aldeia conseguiram os franceses apoderar-se de 1.000 cabras: roubar o gado deve ter sido o mais eficaz método de guerra, dado o regime alimentar dos canários. Entretanto, erguia-se owtra fortaleza, a de Baltarhayz ou Valtarjal, e Jean de Béthencourt enviava os indigenas cativos ou sujeitos para Lançarote, onde iam trabalhar na reparaçāo de fontes e cisternas e na restauraçāo das lavras que Gadifer se vira forçado a destruir (73). Mas já os próprios franceses tinham gado seu na ilha de Erbania, nāo sabemos se pastoreado pelos naturais (é de crer que sim). Com - prosseguimento da ofensiva, os dois reis e todos os indigenas oferecem a submissāo, sendo aqueles batizados em 18 de Janeiro de 1405 (74). Situa-se em seguida a viagem do barāo à Norman-

\footnotetext{
(68). - Idem, cap. IV e V (pág. 6).

(69). - Idem, cap. XXXVII-XXXIX (pág. 37-9).

(70). - Idem, cap. LXI (pág. 63)

(71). - Idem, cap. LXI (pág. 63) e cap. LXXIIr (págs. 7i-8).

(72). - Idem, cap. LXXIV (pag. 79).

(73). - Idem, cap. LXXIII, IXXIV e LXXV (págs. 77-82).

(74). - Idem, cap. LXXVII - LXXIX (págs. 86\%i).
} 
dia e o seu regresso com novas tropas e com familias de colonos, quer lavradores quer mesteirais. Nāo sabemos qual o número de familias que se estabeleceram em Forteventura; as condições em que se deu aqui tal estabelecimento foram as mesmas que em Lançarote. Cada um dos reis recebeu igualmente um solar e 300 ou .400 acres de terras de lavoura. Os impostos foram os mesmos que na primeira ilha, e também ficaram 2 alcaldes encarregados da justiça.

Qual a influência da conquista e da colonizaçăo na sociedade indigena? A luta foi áspera e nāo curta; é natural, por isso, que tenha reduzido o número de habitantes. Bontier e Le Verrier dizem que a ilha é pouco povoada; mas o povoamento era mais aglomerado do que em Lançarote: agrupavam-se em aldeias protegidas por castelos (75). Afigura-se-me plausivel que esta forma de povoamento resultasse da ameaça da pirataria cristā e das constantes guerras entre os dois reis (e estas guerras teriam por fito fazer cativos para os vender aos cristāos?). Na Crónica da Guiné calcula-se o número de homens de peleja de Forteventura em 80 (76) - mais portanto, do que na ilha vizinha. Ora, num dos recontros contra Gadifer, pelejaram uns 50 indigenas (77). Ignoramos qual a contribuiçāo da colonizaçāo francesa para o volume demográfico. No comêço do século seguinte ainda se falava na ilha o dialecto normando $(78)$.

Os colonos devem ter desenvolvido a agricultura e o sistema hidráulico, e sob a sua influência os indígenas de Erbania, como os de Lançarote e Ferro, realizaram grandes progressos na lavou$\mathrm{ra}$, que os dois capelāes jubilosamente registam (cap. XCII, pág. 114). Aos intrusos se deve incontestàvelmente o comêço do fabrico de pāo de cevada e sua inclusāo generalizada na alimentação indigena, de que já Cadamosto foi informado em 1455 (cap. V da Navegaçāo Primeira). Também é de atribuir aos colonos a introduçāo da criação de coelhos, muito importante no início do século XVI (79). Em meados de Quatrocentos a ilha exportava courama, sebo e queijo de leite de cabra, bem como urzela (80). Em Erbania a urzela é muito abundante e veio a constituir, como em Lançarote, monopólio do donatário; os dois capelāes nāo se cansam de lhe enaltecer o valor e chegam a afirmar que é a melhor planta que há em qualquer pais (cap. LXX, pág. 73). A dificul-. dade que de algum modo cerceava o desenvolvimento comercial. da ilha era a ausência de bons portos para naus grandes; os exis-

(75). - Idem, cap. LXX (pág. 74).

(76). - Idem, cap. LXXIX.

(77). - Bontier e Le Verrier, caps. XXXVIII e XXXIX.

(78). - Ch. La Roncière, ob. cit. pág. 88.

(79). - V. Fernandes (pág. 101).

(80). - Cadamosto, Navegạño Primeira, cap. V. 
tentes eram seguros sim, mas só serviam para embarcações pequenas $(81)$.

A terceira ilha conquistada por Jean de Béthencourt foi a do Ferro, a mais ocidental e meridional do arquipélago. Como explicar que a conquista desse assim um salto por cima das restantes ilhas e nāo se tivesse firmado na Palma, onde já começara? É que, por um lado, os indígenas não navegavam (pelo menos regularmente) entre as diferentes ilhas, ao passo que os cristāos dispunham de fáceis comunicações marítimas; e, por outro lado, a ilha do Ferro tinha muito poucos hábitantes quando o barāo decidiu submetê-la. Parece que outrora fôra bem povoada, mas sofreu muitos cativeiros e invasões que a ermaram (82); os cristāos frequentavam-na como raptores de futuros escravos, e só no ano de 1402 , segundo indicam Bontier e Le Verrier, foram cativos 400 indigenas (cap. XLII, pág. 42). Devido a ter sido muito saqueada, teria ficado deserta se nào fôsse o afluxo de colonos franceses (cap. LXXXIV, pág. 100). Na Crónica da Guiné (cap. LXXIX) avalia-se a sua populaçāo em 12 homens de peleja: tratar-se-á em exclusivo dos sobreviventes indígenas ou haverá engano de número? Valentim Fernandes, caracterizando os nativos, diz que "os homẽs gẽtios della erā muy esforçados" e que por isso, e devido às dificuldades do terreno a ilha foi "muyto trabalhosa de ganar" (fol. $156 \mathrm{r}$, pág. 106). A apreciação e a informação são tardias - de um século posteriores à conquista - não sabemos onde o impressor de Morávia as foi beber, e nāo são confirmadas pela História do Descobrimento e Conquista das Canátias, que nāo fala do caráter bélico dos nativos nem deixa a impressāo de que o subjugar a ilha tivesse sido particularmente custoso.

A ilha do Ferro "he de terra muy fragosa", consoante a descreve Valentim Fernandes (83); e esta descriçāo coincide com a de Bontier e Le Verrier, que no-la pintam bela e forte, sem portos bons nem entradas (84), de terreno áspero e quebrado até uma légua do litoral (85). Mas o interior é delicioso, coberto de imen. sos bosques verdejantes de pinheiros e loureiros (cap. XLII), o que o impressor de Morávia também nos diz: "Esta ilha tem muytos aruoredos" (fol. $156 \mathrm{r}$, pág. 106); as águas corriam em abundância e os dois capelāes consideravam-nas deliciosas (cap. XLII e LXV) (86). Na ilha chove com frequência. Na parte mais alta da ilha há árvores que gotejam sempre um liquido claro e formoso, que no século XV se considerava belíssimo para beber (87), e de

(81). - Bontier e Ie Verrier, cap. LXX (pág. $7 t$ ).

(82). - Idem, cap. LXV (pág. 68), cap. XLII (pág. 42) e cap. LXXXIV (pág. 1010).

(83). - Fol. 156 r (pág. 106).

(st). - Ijontier e Le Verrier, cap. IXX.

(85). -- ldem, cap. XILII (pág. 42).

(86). - V. Fernandes escreve: "Nō tem ribeyras nem fontes dagoa" (pág. 106), o que parece ser engano.

(87). - Bontier c Le Verrier, cap. LXV (pág. 69); V. Fernandes, fol. 156 r (pág. 106). 
que bebiam tanto homens como gados. E Valentim Fernandes descreve-nos que uma das árvores excede as outras em altura, e que no seu pé construiram uma espécie de tanque que recolhe as gotas e onde se vai reparar a sêde; e esta árvore era sagrada para os indigenas (88). Esvoaçavam codornizes sem número, falcões, açores, cotovias e pássaros com plumas semelhantes às do faisão e corpo do tamanho de papagaio, de vôo curto (89).

$\mathrm{Na}$ ilha estendem-se bons campos para lavrar, que, na apreciaçāo dos dois capelāes, podem muito bem produzir trigo, vinho e outros frutos. E já no comêço do século se colhia bastante trigo de várias classes (cap. LXV); cem anos mais tarde escreverá Valentim Fernandes: "Em esta ylha do Fero naçe trigo e çeuada" (fol. $156 \mathrm{v}$, pág. 106). O desenvolvimento da lavoura deve atribuir-se em grande parte à acção dos colonos franceses, mas os indígenas deviam já semear os cereais anteriormente a 1402. A criação de gado miúdo era mais variada do que em Lançarote e Erbania: os nativos criavam cabras, ovelhas e porcos em elevado número (90). Esta actividade económica perdurou durante o século de Quatrocentos, pois o impressor de Morávia anotou que a ilha "tem muyto gado" (fol. 156 v, pág. 106). Além disso, segundo Cadamosto encontrava-se na ilha do Ferro "copia di asini salvatichi" (cap. V). Havia também frutas (91). Nestas condições, é de estranhar que Cadamosto, ao expor a alimentaçāo dos habitantes das ilhas cristãs, a considere igual no Ferro ao que é em Lançarote, e Forteventura, tanto mais que o veneziano visitou precisamente aquela ilha e nāo estas duas.

Os indigenas não utilizavam os metais. As lanças - suas únicas armas, além das pedras - eram simples chuços de madeira, sem aste de ferro (92).

É provável que a expediçāo de 1341 visitasse a ilha do Ferro; mas nāo é fácil identificar concretamente qual o passo da descrição de Boccacio que se lhe refere. Na segunda metade do século XIV a ilha deve ter sido frequentemente salteada, a darmos crédito aos dois capelāes franceses. Durante a primeira ausência de Béthencourt, Gadifer percorreu as ilhas para exploraçāo geográfica, e esteve na do Ferro 22 dias (93). Mas a ilha só foi ocupada

(8S). - V. Fernandes, fol. 156 r (pág. 106): "Tem huuma aruore em meio de outras muytas aruores, onde sempre mana nebrina. $\mathrm{E}$ he muyto alta mais q as outras e desta aruore mana agoa cótinuadamente yverno e verão das suas folhas, ajnda $q$ as outras aruores de sua calidade manem tãbem, porem esta mais q outra alguma. I de baixo desta aruore os moradores desta ilha tem feito huum cerco de parede como huum tanque em a se recolne toda esta agoa de que se repayrã os moradores e gaados desta. ilha. $E$ he posta grãde guarda e pena de morte q nenhuum nõ corte ramo desta aruore. IE esta aruore nõ tem nenhuuma feyçã das nossas aruores porem se quer pareçer acerca como a cerejeyra."

(89). - Bontier e Isa Verrier, cap. LXV e XLII.

(90). - Idem.

(91). - Idem, cap. LXV.

(92). - Bontier e Le Verrier, cap. LXV.

(93). - Idem, cap. XLII (pág. 42). 
depois da ida do barāo à Normandia a buscar reforços militares e aliciar colonos - portanto, em 1405. Béthencourt permaneceu no Ferro três meses e os indigenas submetem-se ao seu senhorio; aliás, apesar da pacílica submissāo, o conquistador reparte 31 nativos incluindo o rei - como escravos entre os seus companheiros, a fim de satisfazer a sua cobiça e dispor de terras para distribuir à gente miúda que trouxera de França (94). Na ilha estabeleceram-se 120 familias de lavradores franceses, isentos de impostos durante 9 anos e depois obrigados a pagar o quinto. Para administrar a justiça ficaram dois alcaldes (95).

As exportações da ilha do Ferro eram, em meados do século $\mathrm{XV}$, as mesmas que. as das outras. ilhas cristās, segundo informa Cadamosto (cap. V da Navegaçāo Primeira); portanto: courama, sebo e queijo de leite de cabra, e urzela.

(94). - Idem, cap. IXXXIV (pág. 99-100).

(95). - Idem, cap. LXXXV. 


\section{CAPITULO III}

\section{AS ILHAS PAGÃS: GOMEIRA, GRÃ-CANÁRIA, TENERIFE E PALMA}

As três ilhas de Lançarote, Forteventura e Ferro estavam conquistadas e completamente submetidas em 1405 , e desde logo foram colonizadas por europeus e sofreram a cristianizaçāo com intensidade. Da Ctónica da Gutiné consideram-se estas ilhas plenamente cristās, e o mesmo acontece na Relaçāo, de Diogo Gomes, de algumas décadas posterior. Mas a conquista e cristianizaçăo do resto do arquipélago arrastaram-se lentas, por todo o século $\mathrm{XV}$ - o que significa também que nos é mais fácil conhecer a sociedade indigena na Gomeira, Grā-Canária, Tenerife e Palma. No decurso dessas décadas de transiçāo, porém, a presença dos cristäos nas outras ilhas constitui um factor de perturbaçāo: conta-nos Cadamosto (cap. $\mathrm{V}$ da Navegaçāo Primeira) que os moradores das ilhas cristēis têem por costume andar com as suas fustas a assaltar de noite as ilhas idólatras para aprisionar canários, que enviam para Espanha para serem vendidos como escravos.

Jean de Béthencourt nāo tentou sequer conquistar a Gomeira. $\mathrm{Na}$ viagem de exploraçāo pelo arquipélago que efectuou durante a primeira ausência do seu senhor, Gadifer esteve naquela ilha e ai aprisionou três canários (96). E até o regresso definitivo do barāo à Normandia nāo se torna a falar em visita ou ataque à Gomeira. Maciot de Béthencourt, que ficou como capitāo das ilhas ocupadas, trabalhou por conquistar a Gomeira com o auxílio de castelhanos (97), parece que ainda em vida do tio (98), possìvelmente entre 1418 e 1420 , isto é, entre a alienaçāo das ilhas ao Conde de Niebla e o aprisionamento de Maciot pelos armadores sevilhanos Las Casas. Mas nāo puderam concluir a conquista, embora conseguissem cristianizar parte da populaçāo (99). Em 1445 três caravelas portuguesas aportaram à ilha de Gomeira; e Zurara escreve: "na qual, querendo sair em terra, viram muitos canários, dos quais houveram .segurança antes que de todo saíssem de seus bateis. Os canários lha outorgaram sem nenhuma referta, como homens que tinham suas vontades mais inclinadas a lhe aproveitar que a empecer. Ali chegaram logo dois capitāes daquela ilha, di-

(96). - Bontier e Le Verrier, cap. XLI (pág. 41).

(97). - Cronica da Guine, cap. LXXXX; cf. Barros, Década I, Livro I, cap.

XII.

(98). - Barros, idem.

(99). - Crón. da Guine, cap. LXXIX. 
zendo como eram servidores do Infante D. Henrique, e nāo sem grande razāo, que êles foram já em casa de El-Rei de Castela e de El-Rei de Portugal, e que nunca em algum dêles acharam as mercês que depois houveram do Infante D. Henrique; que sendo em sua casa acharam em êle mui bom acolhimento, enquanto em ela estiveram; e enfim, que os vestira mui bem, e os mandara em seus navios para sua terra, pelo qual eram muito prestes para todo seu serviço." Os portugueses propuzeram-lhes irem em conjunto saltear a ilha da Palma, ao que os canários de bom grado acederam. E Piste, um dos capitães (o outro chamava-se Bruco) foi também na expedição, e os indigenas da Gomeira combateram ao lado dos portugueses contra os indigenas da Palma. A certa altura lê-se: "Porém os cristãos, assim portugueses como os canários..." (100). Os atacantes regressaram pela Gomeira e os portugueses levaram à traição 21 dos seus aliados para Portugal como cativos, mas o Infante mandou-os de novo em liberdade para a, sua ilha nativa. Mais tarde o capitão Piste e alguns dos seus canários vieram a Portugal e parece que por cá ficaram, aqui falecendo (101). Alvaro Dornelas e Joāo Dornelas foram igualmente à Gomeira pedir auxilio para um assalto à ilha de Palma, e de novo os indigenas concordaram com boa vontade; depois do ataque voltaram à Gomeira e Alvaro Dornelas ficou na ilha, ao passo que o primo regressava a Portugal (102). Segundo Diogo Gomes, êste Álvaro Dornelas comandou algumas caravelas do Infante que em 1448 (a data é indicada por Valentim Fernandes) foram atacar a Gomeira, e conquistou e teve algum tempo em seu poder metade da ilha (103). Em 1455 Cadamosto esteve na ilha de passagem para a Guiné, e apresenta-no-la habitada e governada por cristāos, sem esclarecer se indígenas, se castelhanos (mas subordinados ao castelhano Ferreira: no intervalo dera-se o colapso das pretensões henriquinas). Mas a cristianização parece que nāo era integral: efectivamente. Diogo Gomes indica que cêrca de metade da população é cristã e a outra metade continua idólatra. Entrado o último quartel do século, os nativos revoltaram-se e mataram o cavaleiro Pero de Vera, capitāo cristāo da ilha; os espanhois conseguiram, porém, reconquistá-la, e parece que dela expulsaram os canários (104).

Chegaram até nós duas descrições que nos pintam o estado da ilha antes da definitiva ocupação pelos cristāos, e a primeira reporta-se até à fase que precedeu qualquer tentativa europeia de

\footnotetext{
(100). - Idem, cap. LXVIII.

(101). - Idem, cap. LXIX. Zurara viu-os no Algarve, em casa de D. Henrique.

(102). - Idem, cap. LXXXV.

(103). - Cf. V. Fernandes, fol. $154 \overline{\mathbf{r}}$ (pág. 104).

(104). - v. Fernandes, fol. $149 r-$ nota a margem (pág. 101) e fol. $154 r$ (pág. 104).
} 
conquista. Não sabemos por que razão, Diogo Gomes nāo descreve a Gomeira.

A paisagem da Gomeira caracteriza-se por barrancos grandes e profundos. "E he terra de muytas agoas e boas porẽ doentya em sy de febres" (V. Fernandes, fol. 154 r, pág. 104). Existen) dragos e outras espécies de árvores (Bontier e Le Verrier, cap. LXVII). Na ilha habita uma populaçāo numerosa, no dizer de Bontier e Le Verrier (cap. LXVIl, pág. 70); e Zurara especifica (cap. LXXX) que sāo 700 homens de peleja. O volume populacional deve-se possivelmente ao facto de a ilha nāo ter sido tão salteada pelos cristãos como aquelas de que atrás falámos.

Os canários estavam divididos em bandos, cada qual com sua cabeceira (ou chefe), mas tôdas as cabeceiras obedeciam a um chefe supremo, a que a Crónica da Guiné chama duque (cap. LXXX). Porém, noutro capitulo da mesma Crónica (o LXVIII) fala-se em dois capitāes da ilha; ou pertencem ao número das cabeceiras, ou com a cristianizaçāo os insulares que deixaram a idolatria se organizaram sob uma dupla chefia (105). Quanto à organizaçāo das relações sexuais, a Crónica da Guiné nāo é muito clara: lemos, de facto, que as mulheres são quási comuns, mas depois depreendemos que cada homem vive com uma (ou mais?) mulher, que a cortezia lhe impõi ceda ao hóspede de sua casa (106). Sem dúvida que existia grande liberdade de relações sexuais. Nestas circunstâncias, a herança transmite-se por linha feminina: herdam os: filhos das irmās (107). Esta informaçāo significa ainda que já existia a propriedade individual masculina, nāo sabemos, porém. com que amplitude.

Estas gentes da Gomeira enquanto nāo cristās, acreditavam num deus, que talvez fôsse o Sol, como em Tenerife e Palma. Parece que só se importavam com a vida terrena - "em fornizio põem tôda sua bem-aventurança", anota com escândalo a Crónica da Guiné; e acrescenta que dispendem todo o tempo em cantar e bailar, pois o seu vício é folga sem trabalho. Esta última observaçăo descortina-nos a antitese de duas mentalidades económicas que se deparam e contrastam: a mentalidade primitiva, descuidada quanto ao futuro, exalçando como valor máximo a ociosidade, ao passo que a mentalidade da Europa quatrocentista vinca já a necessidade do labor.

A populaçāo tinha um viver primitivo. Todos andavam nus e - que é mais (para estupor da Crónica da Guiné), escarneciam dos vestidos, "dizendo que nāo sāo outra cousa senão sacos em

\footnotetext{
(105). - O cap. LXXX refere-se ao estado da ilha antes da cristianização, 0 cap. LXVIII supối-a já explicitamente.

(106). - Esta cedencia destinar-se-ia a criar um "laço de participação" (no sentido de Lévy-Bruhl) entre o dono da casa e o hóspede (na Grécia homérica ainda tal laco se criava, mas sob forma muito diferente): isto na hipótese de as mulheres estarem divididas, porque se eram comuns já a explicação reside na simples comunidade.

(107). - Crónica da Guiné, cap. LXXX.
} 
que se os homens metem." Desconheciam a arte de edificar casas e viviam em covas e choças (108).

A uma civilização rudimentar correspondia uma economia atrazada. O cultivo da cevada (em que Bontier e Le Ferrier nem sequer falam) era muito restrito e quási sem importância. Criavam-se porcos e cabras, mas em pequena quantidade (109). A alimentação constava principalmente de leite de cabra, ervas e raizes de juncos; raro se adicionava a carne; comiam também "cousas torpes e sujas, assim como ratos, pulgas e piolhos e carrapatos, havendo por boa vianda" (110).

O armamento consistia em chuços curtos (como frechas), aguçados e com a ponta endurecida ao fogo (111).

Entrada a segunda metade do século, porém, a situaçāo parece ser já diferente. Cadamosto esteve na Gomeira e engloba-a, quanto a alimentaçāo e até civilizaçāo, com Lançarote, Forteven- tura e Ferro; quere dizer que a lavoura da cevada e a criaçāo de cabras devem ter efectuado marcados progressos (112). E o quadro económico que meio século depois nos traça Valentim Fernandes contrasta radicalmente com o inicial. No comêço de quinhentos a ilha apresenta-se muito frutífera, com próspera lavoura nāo só de cevada mas também de trigo, com farta criaçāo de tôda a espécie de gado e com abundante produçāo de açucar e vinho (113). No intervalo, situa-se a definitiva conquista e a colonizaçāo da Gomeira pelos castelhanos.

De tôdas as ilhas, é a Grā-Canária a que nos é mais bem conhecida. Descreve-a de maneira bastante completa a narração de Boccacio, de 1341. Nos primórdios de Quatrocentos, pintaram-na com vagar os dois capelāes de Béthencourt. Das quatro a que a Crónica da Guiné consagra alguns capítulos, é a que nessa obra ocupa maior espaço. Diogo Gomes trata também da Grā-Canária, e Valentim Fernandes informa-nos, embora concisamente, sôbre o seu estado depois da conquista castelhana. Em Cadamosto é que quási nāo há indicaçôes a respigar.

A expedição de Tegghia de Corbizzi e Niccoloso de Recco visitou demoradamente a Grä-Canária, entrando numa aldeia da parte setentrional. Ainda no século XIV, alguns cristāos fixaram residência na ilha: Gadifer encontrou aqui o testamento de treze cristāos, datado de 1391, que os indigenas iam matar porque tinham escrito para a Europa a solicitar a conquista; há 7 anos que viviam entre os canários (114). Na primeira viagem de explora-

(108). - Cronica da Guine, cap. LXXX.

(109). - Idem. Bontier e Le Verrier referem a criação de gado menor (cap. LXVII, pág. 70).

(110). - Crón, da Guiné, cap. LXXX.

(111). - Idem.

(112). - Naveracũo Primeira, cap. V.

(113). - Fol. 154 r (pág. 104).

(114). - Bontier e Le Verrier, cap. XL (pág. 41). 
çáo do arquipélago empreendia pelos normandos de Lançarote; Gadifer e os seus desembarcaram na Grā-Canária (115). Em 25 de Julho de 1404 desaferrou de Lançarote uma outra pequena expediçāo que foi reconhecer aquela ilha (116). Vinte ou vinte e um anos mais tarde, D. Fernando de Castro comandava uma armada portuguesa que foi à conquista da Grā-Canária; conseguiu-se cristianizar parte da população, mas não se levou a cabo a conquista devido à falta de mantimentos e, em seguida, à oposiçāo castelhana (117). Algumas décadas depois, Diogo Gomes indica que cêrca de metade dos canários da ilha sāo cristāos. Mas a conquista só prosseguiu em 1486 com Pero de Vera, sendo completada por Afonso de Lugo na última década do século. A conquista foi trabalhosa porque a ilha era muito povoada (118).

A Grā-Canária apresenta o contraste entre as planuras do Norte, propicias à lavoura, e a parte meridional montanhosa (a altitude eleva-se a $1.950 \mathrm{~m}$.), nāo tāo bem cultivada (119). A ilha está revestida, sobretudo ao Sul, de espessas matas de pinheiros, abetos, dragos, zambujeiros, bem como, sobretudo na parte setentrional, de figueiras e tamareiras que produzem boas tâmaras (120); e é terra de muitos ribeiros de água doce e boa (121).

Já em 1341 os indigenas cultivavam, e depois nunca deixaram de cultivar, trigo e cevada, conforme se lê em Boccacio (o trigo muito mais belo do que o europeu, com os grāos mais compridos e grossos, de côr maiś branca) e Bontier e Le Verrier confirmam, esclarecendo que mesmo com a agricultura rudimentar se obtẽem duas colheitas de trigo por ano (cap. LXIX, pág. 71-2) (122). Mas tinham hortas (Boccacio) e colhiam legumes em tôda a ilha (Bontier, idem). A actividade económica repartia-se também pela criação de cabras, ovelhas e porcos, de tudo em grande abastança (123). Ainda estavam à disposição dos nativos figos ("tāo bons que pareciam dos de Cesena" - Boccacio) e tâmaras ("empero não boas", lê-se na Crónica da Guiné, mas os dois capelāes mostram-se de diferente opiniāo). Os canários praticavam a pesca arte em que Bontier e Le Verrier os consideram exímios - com änzóis e nāo sabemos se por outras formas (Crón. da Guiné, cap. LXXIX).

\footnotetext{
(115). - Idem.

(116). - Idem, cap. LXII (págs. 64-5).

(117). - Cr6nica da Guine, cap. LXXIX, e Barros, Década I, Livro. I, cap. XII.

(118). - Valentim Fernandes, fol. $149 \mathrm{r}$ (pág. 101).

(119). - Bontier e Le Verrier, cap. LXIX (pág. 71). Cf. Boccacio.

(120). - Idem. Valentim Fernandes, fol. $149 \mathrm{r}$ (pág. 101): "E he terra de muytos aruoredos". Cf. Boccacio.

(121). - V. Fernandes, idem.

(122). - Crón da Guine, cap. LXXIX: "Hão trigo e cevada."

(123). - Boccaccio "cabras muitas e ovelhas"; Bontier e Le Verrier, cap. LXIX (pág. 72) e LXII (65 - porcos); crón. da Guine, cap. IXXIX ("e têem ovelhas e cabras e porcos abasto"): Diogo Gomes (cabras em abundância).
} 
A alimentaçāo consiste essencialmente da cereais (trigo e cevada), comidos ao natural ou preparados em farinha, e carne $e$ queijo ou manteiga, bem como ervas (legumes, especialmente favas) (124). Nāo sabiam fabricar pāo, mas comeram-no com aprazimento a bordo dos navios em 1341, sem que depois desta data aprendessem a arte do seu fabrico (125). Quanto à carne, indica Diogo Gomes que nāo comem a de cabra; nas outras fontes nāo encontramos tal referência, o que nāo prova que seja errónea: os indigenas podiam utilizar o leite das cabras sem as abater (devido a algum tabu?) e abateram os porcos e ovelhas. Que acto de matar ou de esfolar os animais era considerado impio, provam-no a Crónica da Guiné e a Relaçāo de Diogo Gomes; de carniceiro servia algum cristāo cativo ou algum indigena desprezado e colocado à margem da sociedade. Diogo Gomes declara ainda que os canários nāo se alimentam dos figos que na ilha nascem no lugar de Telle (Telde); sabemos, porém, que a bordo dos navios de 1341 os quatro cativos comeram figos, e na aldeia que os navegadores entāo visitaram êstes encontraram cabazes cheios de figos sêcos, sinal inequivoco de que entravam na alimentação comum. Os canários bebem água e não conhecem o vinho, que os cativos de 1341 recusaram a bordo dos navios cristāos.

Muitos dos canários andavam completamente nus. Outros usavam uma tanga de fôlhas de palma, à maneira de bragas; os navegantes de 1341 descreveram-na assim: "tinham uma corda cingida, da qual pendiam filas de fôlhas de palma espessas e compridas de um a dois palmos no máximo, e com elas cobriam as vergonhas quer de frente quer de trás, a nāo ser que o vento ou outra coisa as levantasse". As fôlhas eram pintadas a amarelo e a vermelho. As mulheres virgens andavam nuas ("nāo considerando vergonha andarem assim", admiravam-se a europeus da expedição trecentista); as que já copularam cobriam as partes com tangas à maneira dos homens (lê-se na descrição de Boccacio) ou com peles (segundo Bontier e Le Verrier). É possivel que a gente comum nada vestisse, ao passo que os nobres se tapassem quer com tangas quer com peles; ou que as peles distinguissem os proeminentes dos plebeus. As peles escolhidas eram as de cabra; coziam-nas com cordões de tripas, com muita arte (126). Nāo tinham panos, e possivelmente ignoravam a arte da tecelagem; ainda

\footnotetext{
(124). - Roccaccio: "Comem também trigo e cerada ìs mãos cheias, queijo e carne. đas quais coisas têem muito e bom" e " $O$ trigo e os cereais comem-nos ou à maneira das aves ou em farinha, sem dêles fazerem pão"; Crón. da Guinc, cap. LXXIX, Diogo Gomes điz que comem aveia.

(125). - Boccaccio: "Mal entraram nos navios começaram a comer figos e pão, que lhes pareceu muito bom. nunca o tendo ate al comido"; Cron. da Guinc, cap. LXXIX: "..., mas falece-lbes o engenho para fazer pão; somente fazem farinha, a qual comem com carne e com manteiga.'.

(126). - Boccaccio; Bontier e Le Verrier. cap. LXDX (págs. 71-2); Crón. da Guine, cap. LXXIX.
} 
no século $\mathrm{XV}$. "nem panos de nenhuma feiçāo lhes praz pouco nem muito, antes escarnecem de quem quer que os preza", consoante lemos na Crónica da Guiné. Os canários lavravam o corpo com tatuagens (127). Caminhavam descalços.

A habitaçāo já nāo é a simples choça ou cova, como noutras ilhas, mas a casa de pedra, construida "com arte maravilhosa", coberta de madeiras enormes e belissimas, $e$ interiormente branqueada, "como se fôsse com gêsso". Estas informações da descriçāo de Boccacio sāo em parte corroboradas pela Crónica da Guiné: " $\therefore$. se nāo algumas coisas que fazem com as pedras, de que se aproveitam em lugar de cuitelos, e assim fazem as casas em que vivem" (cap. LXXIX). As casas tinham portas de madeira (Boccacio).

Da utensilagem de que dispunham, as fontes escritas referem as facas de pedra ("as pedras, de que se aproveitam em lugar de cuitelos") e os anzóis de ferro para pesca (128). O fogo era produzido por friç̧āo: "O fogo acendem com paus, esfregando um com o outro" (129). Nāo têem ouro nem prata nem jóias, o que tudo desprezam. Só apreciam o ferro, que carregam com pedras, fabricando os anzóis. É com os cuitelos de pedra que rapam a barba (130). O seu armamento consiste apenas de pedras de arremêsso e de paus curtos "para dar com êle"; mas eram corajosos e temiveis na peleja; defendendo com denodo a sua ilha (131). Nāo tinham armas defensivas; é certo que, na expediçāo de Julho de 1404 , os normandos viram os indígenas com broqueis; porém, Bontier e Le Verrier indicam que deviam ter sido apanhados aos espanhois noutro tempo (cap. LXII, pág. 65) : tratava-se, pois, da utilizaçāo ocasional de armamento alheio, e que nāo voltou a registar-se.

A Grā-Canária tinha denso povoamento (132). Os navegadores de 1341 julgaram até que era a mais povoada do arquipélago. Parece, porém, tratar-se de um engano, porquanto a Crónica da Guiné e Cadamosto concordam em reservar o primeiro lugar para Tenerife; aliás nāo é impossivel que se tivesse dado na segunda metade do século XIV e primeiras décadas do XV uma evoluçāo demográfica que explicasse a aparente discrepância entre a fonte trecentista e as fontes quatrocentistas: na verdade, a Grā-Canária sofreu maior número de tentativas de conquista e foi mais salteada do que a ilha do Inferno, o que pode muito bem ter provocado um decréscimo populacional. Bontier e Le Verrier apresen-

\footnotetext{
(127). - Bontier e Le Verrier, idem.

(128). - Crón. da Guine, cap. LXXIX.

(129). - Idem.

(130). - . Idem

(131). - Idem.

(132). - Boccaccio; Bontier e Le Verrier, cap. LXIX (pág. 71); Crón. Guine, idem; Cadamosto, Nav. Primeira, cap. V; V. Fernandes, fol. 149 r (pág. 101): "a jnpijnda gente q auia nella."
} 
tam uma avaliaçāo de certo muito exagerada do número de "fidalgos" da ilha: seriam uns 10.000 (cap. LXXXII, págs. 96 e 98); noutro capítulo (XL), contudo, falam tāo só de cêrca de 6.000 varões nobres: se entendessemos aqui no sentido lato de homens de peleja, êste total aproximar-se-ia do que vem na Crónica da Guiné, pois nesta computam-se os homens de peleja em cêrca de 5.000; Cadamosto calcula a população total em 8.000 a 9.000 habitantes, o que parece coadunar-se com o número apresentado por Cerveira-Zurara.

Sabemos já que a populaçāo se acumulava na parte setentrional e se rarefazia na meridional. No comêço do século XV existiam três aldeias principais. No Nordeste, a pouca distância da costa e a duas léguas entre si, ficavam Telde e Aguimes, ambas situadas nas margens de arroios; para Sudeste ficava a aldeia de Arguineguim, no litoral, que, no juizo dos dois capelāes, poderia ser excelente pôrto para naus pequenas (aliás as entradas na ilha eram boas e sem perigo desde que se caminhasse com a sonda) (133). Foi possivelmente em Telde ou na aldeia vizinha que estiveram os florentinos, genoveses e castelhanos de 1341 .

A populaçāo dividia-se em duas classes: gente comum e nobres (134). Segundo a Crónica da Guiné, os nobres têem um número limitado: não hāo-de minguar de cento e noventa, nem chegar a duzentos. As vezes deixadas pelos mortos preenchem-se aos grupos de cinco ou seis; os nobres escolhem entre os filhos dos nobres os que hão-de ir ocupar o lugar dos que faleceram, "em guisa que sempre o conto seja cumprido." Como o patriciado na antiga Roma, êstes nobres é que detinham os segredos da religiāo, e a gente comum limitava-se a crer no que êles determinavam. Aos nobres ainda é que incumbia desflorar tôdas as virgens, :preliminar indispensável para qualquer rapariga se poder casar (ius primae noctis) (135). Nas māos dos 190 a 200 nobres estava todo o govêrno da ilha; mas havia dois reis e um duque (136). Em baixo de tudo, estavam os carniceiros, cuja profissāo era tida por vil, e que por isso viviam fóra dos quadros sociais (137).

Nāo sabemos como estava organizada a familia, mas existia certamente, porquanto se afirma da descrição de Boccacio "As suas mulheres casam-se", e na Crónica da Guiné se fala em "ca-

\footnotetext{
(133). - Bontier e Le Verrier, cap. LXIX (pág. 72).

(134). - Boccaccio; Bontier e Le Verrier, idem e cap. LXXXII; Crón da Guine, cap. LXXIX; Diogo Gomes, Relagão.

(135). - Crón. da Guine, cap. LXXIX.

-(136). - Já na descricãa de Boccaccio se lê: "e, conforme podia deprender-se dos seus actos, mostravam ter um chere, ao qual todos tributávam reverência e obséquio". Quando Gadifer desembarcou numa abra entre Telde e Aguimes, foi informado de que 0 rei indigena estava a 5 léguaś de distância (Bontier e Le Verrier, cap. XL (pág. 40-1); a pequena expedição normanda de Julho de 1404, que passou pela região de Telde e pela de Arguineguim, tambem ouviu falar do rei do país (idem, cap. LXII, pág. 64).

a137). - Cron. da Guiné, cap. LXXiX; e Diogo Gomes, Relasão.
} 
sar", o que igualmente acontece na Relação de Diogo Gomes. O pai apresenta a filha virgem aos nobres; se a consideram já assás gorda, um dêles rompe-a, e o pai volta a levá-la para casa. Após esta cerimónia, o nobre que a desflorou ou o pai escolhe-lhe casamento (138). A filha leva em dote, dado pelo pai, muitas cabras. Se o marido a deseja abandonar, tem de dar 10 cabras, e igual número se de novo a quere para si. Como na Gomeira, a lei da hospitalidade impõi que o dono ceda a mulher ao hóspede e que êste com ela durma (139). Parece que era corrente a relutância, por parte das māes, de amamentarem os filhos, pelo que êstes em geral se criavam a mamar nas tetas das cabras (140).

Os canários adoravam o Sol (141), e parece que acreditavam que o deus recompensa os bons e castiga os maus (142). Tinham um templo, sem pinturas nem ornamentos, onde se erguia uma estátua de pedra, que figurava um homem nu, só com as partes cobertas por fôlhas de palmeira (à moda dos indigenas), segurando na māo uma bola (o Sol?) (143).

Dadas as condições da sua economia e civilizaçāo, nāo admira que a Grä-Canária se desenvolvesse ràpidamente nos últimos anos do século $X V$ e primeiro lustro de quinhentos, isto é, depois da conquista castelhana. Por 1506 a lavoura de trigo e cevada produzia com fartura, e já tinham sido introduzidas e floresciam as novas culturas da cana de açucar e da vinha. Com tal impulso económico, vivia-se na ilha "em muyta abastāça" (144).

E muito provável que na expediçāo de 1341 se tenha avistado a ilha do Inferno ou Tenerife; mas os navios nem sequer a abordaram, porque as tripulações se atemorizaram com o vulcanismo do seu pico, considerando-o um prodígio misterioso. Ainda no século $\mathrm{XV}$ as descrições não se esquecem de pintar o fenómeno: " $E$ na sexta ilha, que é de Tanarife ou do Inferno, porque tem em cima um algar por onde sai sempre fumo,..." lemos na Crónica da Guiné; e Cadamosto escreve: "há una punta, ovver monte, nel mezzo dell'isola a modo di diamante, che è altissima, e continuamente arde." Os normandos que se estabeleceram em Lançarote, Forteventura e Ferro nāo tentaram conquistar a ilha do Inferno nem sequer a foram reconhecer nas suas duas ou três viagens de exploração. Nāo parece que os cristāos a salteassem, pelo menos com frequência, no decurso do século XV. Só em 1496 foi total-

(1.38). - "E depois que algum dos cavaleiros dorme com a moca, então a pode casar seu padre, ou êle com quem lhe prouver" (Crón. da Guinc, cap. LXXIX)

(139). - Diogo Gomes, Relações.

(140). - Crón. da Guinc, cap. LXXIX.

(1.41.). - Gomes.

(142). - Crón. da Guiné, idem.

(143). - Boccaccio.

(144). - Valentim Fernandes, fol. $149 \mathrm{r}$ (pág. 101). 
mente conquistada pelos castelhanos, depois de luta demorada e áspera (145).

A paisagem da ilha apresentava como nota dominante o elevado monte central (altitude de $3.707 \mathrm{~m}$.) sempre com fumo; Diogo Gomes, numa expressāo feliz, compara-a a um pão de açucar devido à sua forma aguda. Ao redor da grande montanha saiam barrancos com florestas de dragos e com águas correntes (146). Valentim Fernandes fala igualmente nos seus muitos arvoredos de pinhos e outras árvores e das muitas ribeiras e boas, sublinhando que há águas em muita abastança (147). Também Diogo Gomes diz: "et sunt in insulis illis multi arbores multarum specierum et flumina et aues." No sopé do monte estendem-se terrenos muito bons para lavoura, conforme indicam os dois capelāes (148) e Diogo Gomes muito mais tarde confirma (149). O clima da ilha é muito benigno: pouco frio se sente, a temperatura mantém-se quente (150).

Em Inferno vivia uma populaçāo numerosa no comêço do século XV, segundo informam Bontier e Le Verrier (cap. LXVIII). $\mathrm{Na}$ Crónica da Guiné calcula-se o número de homens de peleja em 6.000 (cap. LXXIX). Algum tempo depois, em 1455, Cadamosto computava em 14.000 a 15.000 habitantes o total da populaçā̃o da ilha (151). Diogo Gomes afasta-se dêstes cálculos, porquanto apresenta o número de 23.000 homens referindo-se a um pessado ignoramos se próximo ou remoto (152): seja como fôr, parece de rejeitar tal computo como fortemente exagerado (mas também é muito possivel que haja êrro de cópia, por 13.000 , o que se aproximaria de Cadamosto).

Cultivavam-se os cereais - trigo e cevada - e os legumes, quer uns quer outros em muita abastança (153). A colheita fazia-se nos meses de Março e Abril, devido ao clima quente da ilha (154). Criavam-se muitos porcos, ovelhas e cabras - declara-se na Crónica da Guiné (cap. LXXXI), e Cadamosto indica que existe abundância de leite de cabra. Além disso, os indígenas tinham ao seu dispôr fruta com fartura, especialmente os figos (155). Praticavam ainda a pesca com anzol, que fabricavam de chifre de cabra, consoante nos diz Diogo Gomes (156).

(145). - Idem, fol. $152 \mathrm{r}$ (pág. 103): "Acabou se de cõquistar esta ilha anno de 1496 per huum caualleyro chamado Alonso de Lugo cõ muyto trabaho e perda de muytos homens, per mãdado delrey Dó Fernãdo."

(146). - Izontier e Le Verrier, cap. LXVIII.

(147). - Fol. $152 \mathrm{r}$ (pág. 103).

(118). - Cap. LXVIIJ.

(149). - "In pede istius montis est valde bona terra et fertilis."

(1no). - Cadamosto, Nav. Primeira, cap. V.

(151). - Idem.

(152). - "... et dicunt, quod erant ibi 23.000 hominum."

(153). - Cr6n. da Guine, cap. LXXXI.

(154). - Cadamosto, cap. V: " $\mathrm{E}$ per esser il paese molto caldo, raccolgono le sue biade del mese di marzo e d'aprile."

(155). - Idem.

(156). - "Hamos, cum quibus isti capiunt pisces, faciunt de cornibus caprarum." 
A alimentação consiste essencialmente de cevada, carne, leite de cabra e figos: assim pelo menos a enumera Cadamosto (cap. V da Nav. Primeira).

Os canários de Tenerife nāo edificavam casas, ao contrário dos da Grā-Canária (157). As suas habitações eram as grutas $e$ as cavernas das montanhas (158). Escreve-se na Crónica da Guiné que residem em choças e covas (159); mas Cadamosto afirma que "Non hanno case di muro nè di paglia", o que, na segunda parte da frase, contradiz aquela informaçāo da existência de choças.

A maior parte da populaçāo andava nua. Mas os nobres (Cadamosto diz apenas: alguns canários, mas é licito supor que se trata da classe privilegiada) cobriam-se com peles de cabra, uma pela frente e outra pelas costas. Da Crónica da Guiné lê-se simplesmente: "e andam vestidos de peles", sem restringir tal informação a um sector da populaçāo; mas a ausência de restriçāo nāo basta talvez para supormos que êste texto nega o do navegador veneziano. Para defesa do frio (aliás quási inexistente) alguns indigenas untam a pele com uma mistura de sebo de bode e de suco de certas ervas (160). A pintura da pele com suco de ervas verdes, vermelhas e amarelas era muito apreciada como enfeite tanto por homens como por mulheres, consoante anota Cadamosto.

$\mathrm{O}$ armamento compunha-se de pedras, que arremessavam, e de astes de âmago de pinho, como grandes dardos, com um corno aguçado a servir de ponta, ou afiadas, sêcas e tostadas ao fogo para endurecerem (161). Os canários de Tenerife "sāo homens fortes e ardidos", diz a Crónica da Guiné; e Diogo Gomes, mencionando embora a sua pequena estatura, considera-os ferozes na peleja. Já Bontier e Le Verrier tinham proclamado muito antes que êstes insulares sāo de todos os mais ousados, e que por isso ainda nenhum fôra cativo até essa data (cap. LXVIII). A ilha vivia em permanente estado de guerra, e os indigenas matavam-se entre si como animais (162).

Existem em Tenerife nove senhores (a que Cadamosto chama duques, e Zurara reis), cada qual à frente de uma tribo. Diogo Gomes fala apenas de três reis: ou êste número está errado, ou no. intervalo dera-se uma concentraçāo do poder quer pela reduçāo do número de tribos e de chefes, quer pelo aparecimento de uma categoria dirigente acima dos duques. $O$ senhorio não se trans-

\footnotetext{
(157). - Crón. da Guine, cap. LXXXI; Cadamosto, cap. V.

(158). - Cadamosto, idem.

(159). - Cap. LXXXY.

(160) . - Cadamosto, Idem.

(161). - Idem: "Non hanno altre armi, che pietre, e mazze a modo di dardi, e alla punta mettono un corno aguzzo in luogo di ferro: le altre che non hanno corno sono abbruciate nella punta, e fassi quel legno duro come ferro; e con quello offendono." ; Crón. da Guiné, cap. LXXXI.

(162). - "e pelejam uns com os outros, no que é todo seu principal cuidado" (Crón. da Guine, cap. LXXXI); "E fanno alle volte fra loro guerre, ammazzandosi come bestie" (Cadamosto).
} 
mite hereditàriamente, passa do chefe morto para o individuo mais poderoso: claro que a ausência de regra sucessória dava ensejo a ásperas lutas pelo poder (163). Como nas outras ilhas, a sociedade está dividida em gente honrada e gente comum, conforme dá a entender o texto de Diogo Gomes.

As mulheres nāo sāo comuns, antes cada homem tem mulheres certas (164). Por conseguinte, existe a família, que é de tipo poligâmico, não estando limitado o número de esposas: cada qual tem tantas quantas quere (165). Mas o casamento só pode efectuar-se depois do desfloramento ritual da virgem pelo senhor da tribo a que pertence (166), rito análogo ao que vimos na Grā-Canária.

Os canários desta ilha "creem que há aí Deus" diz-nos a Crónica da Guiné. Diogo Gomes esclarece que por deus adoram o Sol; e Cadamosto é ainda mais explícito: "adorano, alcuni il sole, altri la luna e altri pianeti". Conhecemos os seus ritos relacionados com a realeza, embora as fontes talvez não sejam a êste respeito perfeitamente ajustáveis. Segundo Cadamosto, quando ascende ao senhorio um novo senhor, um dos seus homens oferece-se para morrer por amor dêle e para honrar a festa; junto a um precipicio efectuam-se certos actos e pronunciam-se certas palavras rituais, e em seguida o que vai sacrificar-se atira-se para o abismo, esfrangalhando-se em pedaços com a queda. O senhor fica obrigado a galardoar e a honrar a familia do que se sacrificou. Diogo Gomes relata que quando um rei morre, lhe extraem as visceras e as metem numa caixa feita de folhas de palmeira; e um homem, que por sua vontade própria para tal se oferece, leva consigo a caixa e precipita-se de um lugar perigoso num monte para o mar, encomendando-lhe os assistentes saudações e recados para os parentes mortos. E o almoxarife de Sintra descreve ainda que mumificam o cadáver do rei morto, enchendo-o de manteiga, atravessam-no com um espêto e colocam-no numa caverna; à entrada fica de guarda um homem honrado durante um ano: se neste tempo cairem os cabelos e a pele do defunto, o guardiāo passa a ser considerado grande pecador, de contrário consideram-no pessoa de bem; neste segundo caso realiza-se um banquete ritual e prestam-lhe as maiores homenagens, após o que se lança, igualmente ao mar do mesmo local, para ir acompanhar o rei morto. Valentim Fernandes acrescenta que os descendentes dos que se lançaram do penedo ao mar ascendiam a fidalgos (fol. 153 v, pág. 104) - o que concorda de certo modo com as palavras do navegador veneziano. A versāo da Crónica da Guiné difere da que resumimos: o cadáver

(163). - Cadamosto, cap. $Y$ da Navegaç̃o Primeira.

(16t). - Idem; Crón. da Guinc, idem.

(165). - Cadamosto, idem. "e non torriano femmine vergini, se prima non dormissero col signor suo una notte; e questo lo reputano grande onore". Estas últimas palavras sugerem com clareza que se tratava de um rito. 
do rei estaria com a tribo até a morte do seu sucessor; quando êste morre, lançam aquele de um algar, dizendo-lhe que se vá à salvaçāo. Em suma; parece que existiam dois sacrifícios rituais: um pelo rei morto e o outro pelo novo rei. Quanto ao cadáver do rei morto, a informaçāo correcta é a de Diogo Gomes, pois que no século XVII um médico europeu conseguiu ver algumas grutas-túmulos, onde estavam os cadáveres de pé ou deitados em camas de madeira, e no século XVIII explorou-se outra gruta, onde se encontraram mais de mil múmias. $E_{m} 1652$, era tradição entre os guanchos que existira outrora uma tribo sagrada, cujos sacerdotes nāo podiam casar-se com mulheres de outras tribos, e que tinham por missāo embalsamar os cadáveres (167).

Depois da conquista castelhana e num intervalo de poucos anos, a ilha do Inferno desenvolveu-se intensamente sob o ponto de vista económico. Tudo se dava na ilha em muita abastança. Produziam-se trigo, açucar e vinho com abundância; fabricava-se grande quantidade de breu, extraido dos extensos pinhais; continuava a fazer-se farta criaçāo de porcos, ovelhas e cabras (168).

A primeira expediçāo de reconhecimento do arquipélago, empreendida por Gadifer de la Salle, tomou pôrto na ilha de Palma e fêz aguada num riacho (169). Mais tarde os normandos voltaram aqui e sustentaram guerra contra os canários, retirando-se, porém, sem alcançar êxito decisivo (170). É certo que, ao falarem da colonizaçāo das ilhas em 1405, os dois capelāes declaram que a Palma estava conquistada (171). Mas não parece que assim tenha acontecido. A Crónica da Guiné, Cadamosto e Diogo Gomes mostram a ilha integralmente idólatra. Só em 1495 a Palma foi por completo conquistada, por Alonso de Lugo (172).

$\mathrm{Na}$ opiniāo de Bontier e Le Verrier, a Palma é de tôdas a ilha mais deliciosa. E com tal opiniāo concorda Cadamosto, ao escrever: "é bellissima isola a vedere." Pela ilha desdobram-se extensos pinhais e bosques de dragoeiros e árvores de leite medicinal (173). Também a revestiam tamareiras e palmeiras (Munzer, Itinetário, pág. 38). Correm vários arroios, de modo que há muitas e boas águas (174). A terra em si é fragosa (V. Fernandes). - a altitude máxima atinge $2.356 \mathrm{~m}$. - mas extendem-se bons tractos de terreno propicios à lavoura e os pastos abundam (Bontier e La Verrier). Os ares sāo muito sāos (175).

\footnotetext{
(167). - La Roncière: Histoire da la Decouverte de la Terre, pág. 88.

(168). - Valentim Fernandes, fol. $152 \mathrm{r}$ (pág. 103).

(169). - Bontier e le Verrier, cap. XLIII (pág. 42).

(170). - Idem, LXXXIV (pág. 99).

(171.). - Idem, LXXXV (pág. 100).

(172). - V Fernandes, fol. $155 \mathrm{r}$ (pá. 105)

(173). - Bontier e Le Verrier, cap. LXVI (pág. 69); V. Fernandes, fol. 155 r (pag. 105) : "Tem muyto aruoredo gräde e pequeno de toda a sorte, e grãdes pinhaes".

(174). - Idem.

(175). - Bontier e le Verrier, idem.
} 
Parece que no comêço do século XV a ilha era bem povoada, - que se explicaria segundo os dois capelāes, por nāo ter sido saqueada como as outras (176). A partir desta data, porém, os cristāos renovaram os ataques tomando por bases as ilhas já colonizadas, e na Crónica da Guiné afirma-se que a populaçāo é pouco numerosa, existindo sòmente 500 homens de peleja (cap. LXXXII). Alguns anos mais tarde, Cadamosto também declara "la Palma fa poca gente". Diogo Gomes conta que os indigenas resolveram que a populaçāo nāo pudesse ultrapassar um número determinado, e por isso matam as crianças ou os estrangeiros que excedem êsso número.

A alimentaçāo dos canários da Palma constava ùnicamente de carne de ovelha, leite e ervas; nāo cultivavam legumes e depreende-se também que nāo cultivavam cereais. Nāo comiam peixe nem conheciam a arte da pesca (177).

$\mathrm{O}$ armamento compunha-se de astes com um corno agudo a servir de ponta e outro corno, nāo agudo este, a fazer de conto (178). Os nativos sāo de alta estatura e ferozes na peleja (Diogo Gomes).

Quanto à religiāo, a Ctónica da Guiné e Diogo Gomes contradizem-se. Naquela lemos que "não sabem conhecer Deus, nem fé nenhuma, senāo pensam que creem como o outro gado", ao passo que na Relação se afirma que "Por Deus adoram o Sol", como os de Tenerife.

Da organizaçāo social-política, sabemos apenas que existiam reis (Crónica da Guiné, cap. LXXXII).

O nivel da civilizaçāo era muito baixo. "Sāo muito bestiais" diz a Crónica da Guiné dos canários da Palma; e Diogo Gomes confirma: "et sunt rustici siluestres".

Mas com a ocupaçāo a ilha progrediu econòmicamente a olhos vistos. Ao entrar-se no segundo lustro de quinhentos, era já muito frutífera de trigo e cevada - os mais formosos do mundo - e de tudo o que se nela plantava. Criavam-se as mais variadas espécies de gado. Produzia-se muito mel, por alguns considerado o melhor do mundo. Em meados do século XVI parece que atingiu ainda maior prosperidade: abundava entāo de vinhos, carnes, queijos e açúcares.

E que, com a criaçāo do mundo atlântico, as Canárias entram em novo ciclo económico. Escala das frotas que de Sevilha e Cádiz zarpam para o Novo Mundo, desde fins do século XV, a procura crescente das escápulas do outro lado do Atlântico fustiga a sua produção e enriquece-a. Desde comêços do século XVI o açúcar canariano escoa-se para Antuérpia, enquanto os cereais do ar-

$.(176) .-$ Idem.

(177). - Crón. da Guine, cap. LXXXII.

(178). - Idem. 
quipélago vāo abastecer os presídios marroquinos, as cidades peninsulares e até a Madeira. Desta ilha e dos Açores receberá o. ouro e a prata que as velas castelhanas trazem das Indias Ocidentais, e ai desembarcam de contrabando na escala da viagem de regresso. As Canárias deixam de ser coutada de caça ao escravo. Mas se já nāo fornecem a māo-de-obra, passam a pesar no complexo atlântico graças à sua indústria açucareira, à sua viticultura e criaçāo de gado, às côres para a tinturaria.

\section{VITORINO MAGALH $\tilde{A E S ~ G O D I N H O ~}$}

do "Centre National de la Recherche Scientifique". Paris. 